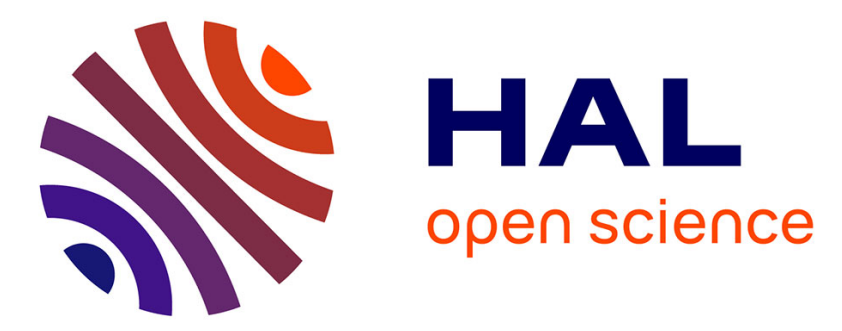

\title{
Multistage genesis of the late Cretaceous manganese karst-hosted Tasdremt deposit (High Atlas, Morocco)
}

Augustin Dekoninck, Gilles Ruffet, Yves Missenard, Oriane Parizot, Mohamed Magoua, Abdellah Mouttaqi, Gaëtan Rochez, Johan Yans

\section{- To cite this version:}

Augustin Dekoninck, Gilles Ruffet, Yves Missenard, Oriane Parizot, Mohamed Magoua, et al.. Multistage genesis of the late Cretaceous manganese karst-hosted Tasdremt deposit (High Atlas, Morocco). Mineralium Deposita, 2021, 56 (5), pp.935-956. 10.1007/s00126-020-01017-0 . insu-02966596

\section{HAL Id: insu-02966596 \\ https://hal-insu.archives-ouvertes.fr/insu-02966596}

Submitted on 15 Oct 2020

HAL is a multi-disciplinary open access archive for the deposit and dissemination of scientific research documents, whether they are published or not. The documents may come from teaching and research institutions in France or abroad, or from public or private research centers.
L'archive ouverte pluridisciplinaire HAL, est destinée au dépôt et à la diffusion de documents scientifiques de niveau recherche, publiés ou non, émanant des établissements d'enseignement et de recherche français ou étrangers, des laboratoires publics ou privés. 


\section{Article}

\section{Multistage genesis of the late Cretaceous manganese karst- hosted Tasdremt deposit (High Atlas, Morocco)}

Augustin Dekoninck, $1 \square$

Email augustin.dekoninck@unamur.be

Gilles Ruffet, 2,3

Yves Missenard, 4

Oriane Parizot, 4

Mohamed Magoua, 5

Abdellah Mouttaqi, 5 
Gaëtan Rochez, 1

Johan Yans, 1

1 Institute of Life-Earth-Environment (ILEE), Université de Namur, 61 rue de Bruxelles, B-5000 Namur, Belgium AQ1

2 CNRS (CNRS/INSU) UMR 6118, Géosciences Rennes, F-35042 Rennes Cedex, France

3 Université de Rennes, CNRS, Géosciences Rennes, UMR 6118, 35000 Rennes, France

4 Université Paris-Saclay, CNRS, GEOPS, 91405 Orsay, France

5 Office National des Mines et des Hydrocarbures, BP 99, Rabat, Morocco

Received: 12 June 2019 / Accepted: 18 September 2020

\section{Abstract}

The eastern part of the Souss Basin (Morocco) contains several Mn deposits in the Tasdremt district. Three Mn orebodies occur within the Cenomanian-Turonian dolostones and the Senonian (Coniacian to Maastrichtian) detrital series, the main orebody being located at the boundary between them. The Mn ores consist of coronadite group minerals, mostly coronadite and hollandite, in a karstified dolostone. New field observations, petrographic analyses, and geochemical data define the Tasdremt deposits as a karst-hosted accumulation (11-60 wt.\% Mn), particularly enriched in Ba (1.5-

8.2 wt.\%) and $\mathrm{Pb}(1.0-5.04 .88$ wt.\%) with poor contaminations in $\mathrm{Al}, \mathrm{Fe}$, and $\mathrm{P}$. This study shows that the ore-forming process is similar to that occurring in the Imini C3 level, located $\sim 100 \mathrm{~km}$ to the north-east. Such similarities with the high-grade pyrolusite-bearing ore suggest that the Tasdremt deposit is a lateral equivalent of the Imini deposits. However, the scarcity of pyrolusite in Tasdremt results in lower Mn grades, the Tasdremt ores being considered an 
aborted/incomplete system in comparison with the Imini deposits.

yields late Cretaceous ages, defining three phases at $\sim 91.5 \mathrm{Ma}, \sim 77.5-82 \mathrm{Ma}$, and $\sim 65-67 \mathrm{Ma}$. Although the source of metals remains hypothetical, mineralizing fluids were carried by $\mathrm{O}_{2}$-free groundwater that mixed with $\mathrm{O}_{2}$-rich shallow meteoric waters at the Tasdremt depositional site. The dissolution of the host dolostones and the karst environment have

provided suitable conditions for the precipitation of Mn oxides, causing the coeval increase of $\mathrm{pH}$ and Eh, respectively. The Early Atlasic deformation during the Late Cretaceous is associated with mineralization events and was responsible for creation of low stand reliefs from Tasdremt to Imini. This period enabled karstification and mineralization. Connecting the Tasdremt deposits to other African Mn deposits is difficult since the latter consist of laterite resting above Paleoproterozoic $\mathrm{Mn}$ protores, and consequently formed under different conditions from karst-hosted deposits. It is likely that other Mn occurrences formed along the Atlas belt in similar settings.

\section{Keywords}

Manganese deposit

Tasdremt

Imini

${ }^{40} \mathrm{Ar} /{ }^{39} \mathrm{Ar}$

K-Mn oxides

Karst

Morocco

Editorial handling: H. A. Gilg

\section{Electronic supplementary material}

The online version of this article (https://doi.org/10.1007/s00126-020-01017-0) contains supplementary material, which is available to authorized users.

\section{Introduction}


Manganese deposits are widespread in Morocco, especially in the Moroccan Atlas and Anti-Atlas. The most important ones are located in the districts of Bou Arfa (Pouit 1980; Lafforgue et al. 2015; Lafforgue 2016), Ouarzazate (Bouladon et al. 1955; Jouravsky 1963; Jouravsky and Pouit 1963; Choubert and Faure-Muret 1973; Pouit 1980; Lippolt and Hautmann 1995), and Imini (Fig. 1a; Thein 1990; Lalaoui et al. 1991; Gutzmer et al. 2006; Dekoninck et al. 2016a, 2016b). The Neoproterozoic volcanosedimentary Tiouine ores (Ouarzazate district) and the karst-hosted Imini deposits are the only currently mined Mn deposits with commercial Mn products (Fig. 1b). In 1951, Bouladon and Meune (1951) investigated Mn occurrences 60-100 km to the south-west of the Imini district, in the Tasdremt area (Fig. 1b; Souss Basin). Although the Mn mineralization in Tasdremt shows significant differences with the Imini ores, including lower grades and discontinuous orebodies, they still display common features since they are hosted in Cretaceous dolostones. The ore was sporadically mined from 1930 to 1960 by the "Omnium Minier Nord Africain" (until 1949) and then by artisanal miners. Only 25,000 t of manganese ore (42-45\% Mn) were extracted from the Tasdremt deposits $(22,000$ in Tasdremt and 3000 in Aoufour; Lesavre 1975) because of contaminants such as $\mathrm{Pb}(\sim 5-7 \%)$ and $\mathrm{Ba}(\sim 6 \%$; Bouladon and Meune 1951) and the scarcity in cation-free Mn oxides, such as pyrolusite. The upper C3 Mn orebody of the Imini deposits contains similar Pb concentrations due to Pb-rich hollandite and coronadite (Gutzmer et al. 2006; Dekoninck et al. 2016a, 2016b). Therefore, the Tasdremt manganese deposit could be considered as a potential equivalent of the high-grade Imini ores (Bouladon and Meune 1951; Pouit 1980; Office National des Mines et des Hydrocarbures 2016). These deposits are separated by the Siroua Miocene volcanic complex, over which Mn occurrences are identified in Cretaceous rocks (Fig. 1b; Bouladon and Jouravsky 1952; Gresse et al. 2000; Thomas et al. 2000).

\section{Fig. 1}

a Location of the Tasdremt and Imini areas in the structural map of North Africa. b Geological map of Cretaceous sediments, Neogene volcanism, and Mn occurrences (from Hollard 1985). c Simplified geological map of the Tasdremt area, showing the location of the Tiranimine, Tasdremt, and Aoufour mining sites (modified after Choubert 1957; Hollard 1985; Parizot 2017)

$\mathrm{AQ2}$ 


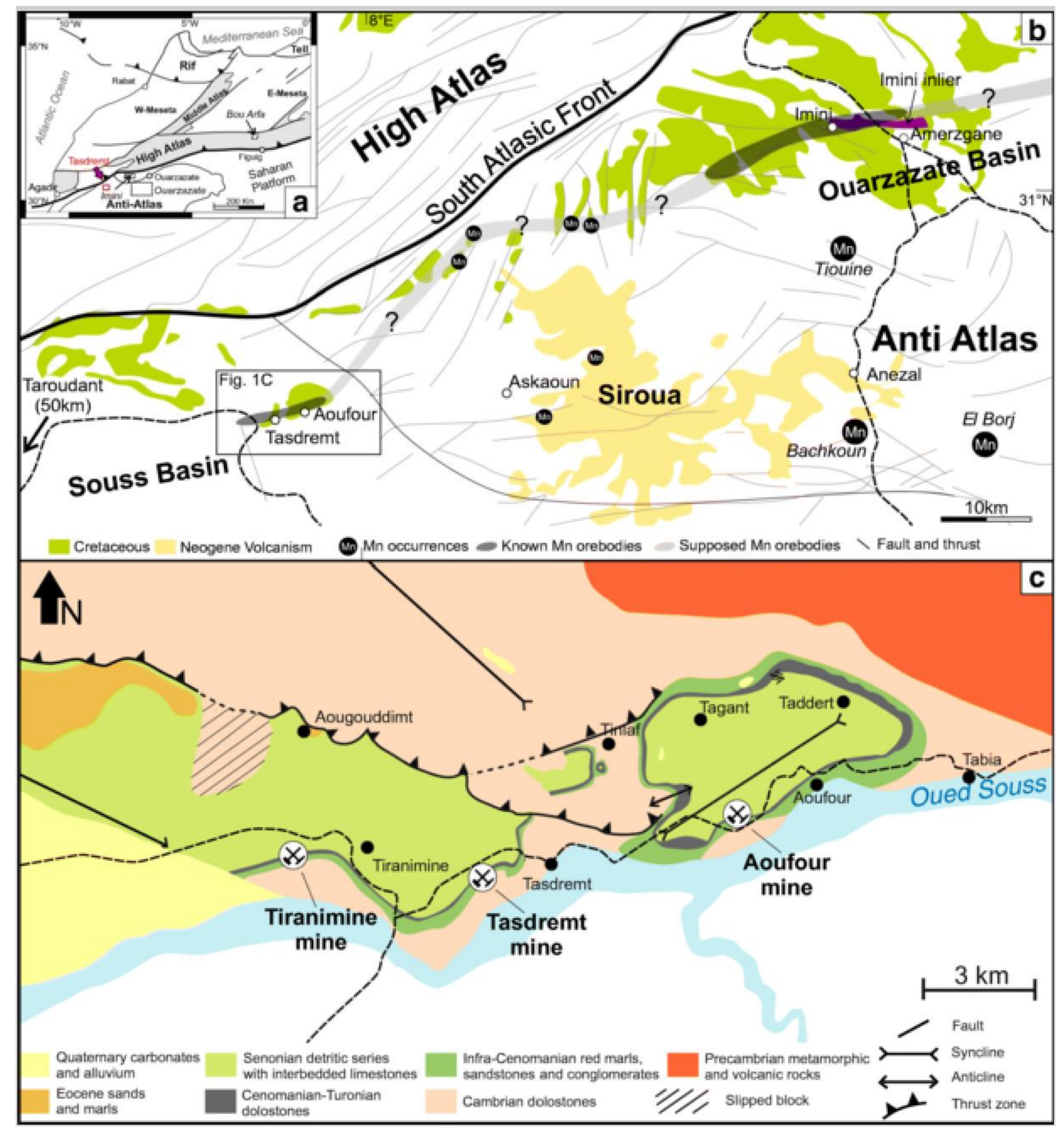


In this paper, we investigate the Tasdremt ores and their genetic relation to the nearby Imini mineralization with a systematic study of their mineralogy, petrography, chemistry and the age of Mn oxide precipitation.

\section{Geological setting}

The Tasdremt district is located in the eastern termination of the Souss Basin - between the Anti-Atlas (south), the High Atlas (north) and the Siroua plateau (east) -, $70 \mathrm{~km}$ east of Taroudant, and $90 \mathrm{~km}$ south-west of the Imini manganese mine (Fig. 1 a and b). The manganese ores are hosted in Cretaceous rocks (Figs. 1b, c and 2; Bouladon 1948).

\section{Fig. 2}

Simplified stratigraphic column of the Tasdremt area, showing the three manganiferous levels (modified after Bouladon and Meune 1951; Ambroggi 1963) 


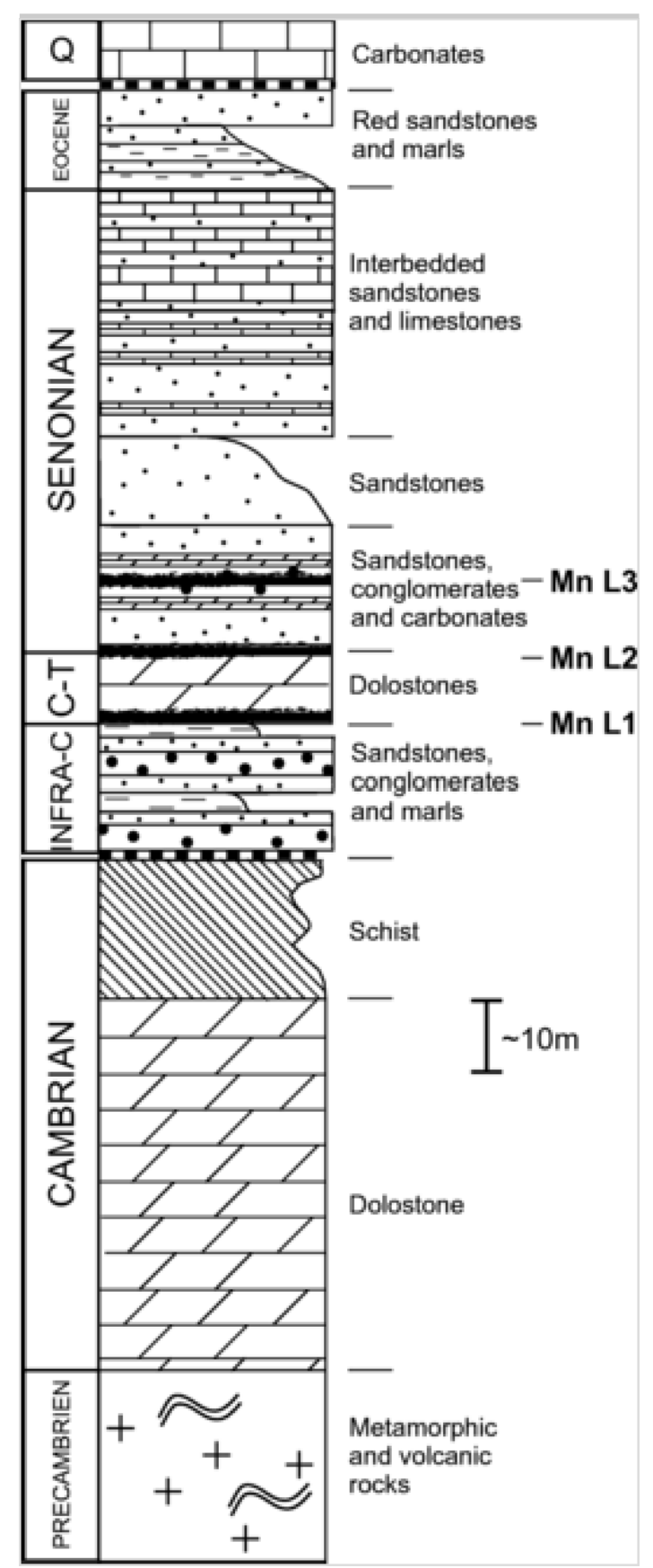


The Anti-Atlas has undergone several folding events during the Panafrican and Variscan orogenic cycles (Gasquet et al. 2005; Youbi et al. 2013; Michard et al. 2017). The Atlas is an intraplate belt that was structured during a late Eocene and a late Pliocene-Quaternary event, mostly due to the distal effects of the Alpine orogeny (Frizon de Lamotte et al. 2000, 2008, 2009; Leprêtre et al. 2015b). Because of the anomalously high elevation and lack of crustal roots, several authors have proposed that a thinned lithosphere supports the current topography of the High Atlas, the Middle Atlas and the Anti-Atlas in Morocco. This deep structure was superimposed to the former tectonic structures of the area during an Early-Middle Miocene doming (Seber et al. 1996; Zeyen et al. 2005; Teixell et al. 2005; Missenard et al. 2006, 2007, 2008; Fullea et al. 2007, 2010; Jiménez-Munt et al. 2011; Gouiza et al. 2017). Therefore, the High Atlas results from (i) a Cenozoic tectonic inversion, and (ii) a thermal uplift associated with the Neogene alkaline volcanism in the Siroua area (Fig. 1b). This uplift is likely to have dismantled Eocene foreland basins over the Siroua plateau (Missenard et al. 2006; Frizon de Lamotte et al. 2009). In the south, low temperature thermochronological investigations (Ruiz et al. 2011; Leprêtre et al. 2015a, 2017; Gouiza et al. 2017) revealed that the Anti-Atlas (Fig. 1) experienced major vertical movements through Mesozoic and Cenozoic times. The Late Triassic to Jurassic exhumation of the Anti-Atlas could have been driven by a rift shoulder effect (Gouiza et al. 2017). After a Late Jurassic to Early Cretaceous subsidence, the Anti-Atlas was exhumed again during the Aptian-Albian, which coincided with changes in the plate tectonic motion initiated by the convergence of Africa and Eurasia (Frizon de Lamotte et al. 2009). Moreover, an angular unconformity between Senonian (Coniacian to Maastrichtian) and Eocene sediments on the northern flank of the High Atlas implies a late Cretaceous event (Froitzheim 1984; Leprêtre et al. 2018).

The Cretaceous succession lies unconformably over the Paleozoic basement (Fig. 2), which consists of a fine-grained, massive, gray Early Cambrian dolostone (Figs. 1c, 2, and 3a; early Georgian) in the Tasdremt area. Late Cambrian to possibly Ordovician red and gray marls and schists progressively crop out to the east (Neltner 1938; Dresch 1941). These Paleozoic rocks are cut by a pre-Cenomanian paleosurface (Fig. 3a). Cambrian dolostones, $\sim 3 \mathrm{~km}$ south of Tasdremt, host MnFe veins (Mn carbonates and pyrite) capped by gossans (coronadite and goethite), which indicates pre-Cretaceous Mn mineralization in the area (Bouladon and Meune 1951). These veins are also well-known in the Neoproterozoic volcanic rocks of the Anti-Atlas (Bouladon et al. 1955; Pouit and Jouravsky 1962; Jouravsky 1963; Jouravsky and Pouit 1963; Choubert and Faure-Muret 1973; Pouit 1980; Lippolt and Hautmann 1995). The Cretaceous sedimentation is a transgressive succession of (1) a 0-30 m thick detrital series (Figs. 2 and 3 a and b; infra-Cenomanian), (2) a 0-20 m thick 
Cenomanian-Turonian dolostones (Figs. 2 and 3b), and (3) a 70-200 m thick Senonian continental detrital sedimentation (Figs. 2 and $3 \mathrm{c}$ and $\mathrm{d}$ ):

(1) The infra-Cenomanian sedimentary rocks consist of red sandstones and conglomerates reworking some blocks of the Lower Cambrian dolostones, which are interbedded with red clay levels (Figs. 2 and 3 a and b). Paleosoils within these levels show roots replaced by Mn oxides.

(2) From base to top, the Cenomanian-Turonian (CT) dolostones are subdivided into (i) a yellow/gray dolostone containing urchin fossils at the base (2-14 m thick), and (ii) a pinkish/white fossiliferous dolostone (Figs. 2 and 4 ; $1-$ $8 \mathrm{~m}$ thick). The siliciclastic content of the CT dolostone increases toward the top of the sequence. There is no evidence of the early Turonian cherty dolostone (Rhalmi et al. 2000).

(3) The Senonian series is mostly detrital but differs from the infra-Cenomanian by its higher content in dolomite. Sandy dolomitic levels are interbedded with conglomerates and sandstones in the first 20-50 m, and overlain by red sandstones for the next 50-150 m (Fig. 3d). The upper part contains red sandstones alternating with white limestone in the Tasdremt area (Figs. 2 and 3d; Bouladon and Meune 1951). The boundary with the underlying CT is characterized by an erosional surface and reworked blocks of Mn ore (Fig. 3c-f).

\section{Fig. 3}

a Angular unconformity between the Cambrian dolostones and the Cretaceous succession at Tasdremt. b L1 Mn ore level at the boundary between red sandstones (infra-Cenomanian) and dolostones (Cenomanian) at Tiranimine. c L2 orebody in the Senonian conglomerates and sandstones at Tasdremt. d Upper L3 orebody in a sandy limestone level (Senonian) in Tasdremt. manganiferous level at the boundary between the lower fossiliferous dolostone and the upper Senonian conglomerates in the Aoufour mine. The ore is a breccia delimited by a paleosurface. f Brecciated L2 Mn ore on the top of the fossiliferous dolostone in Aoufour 

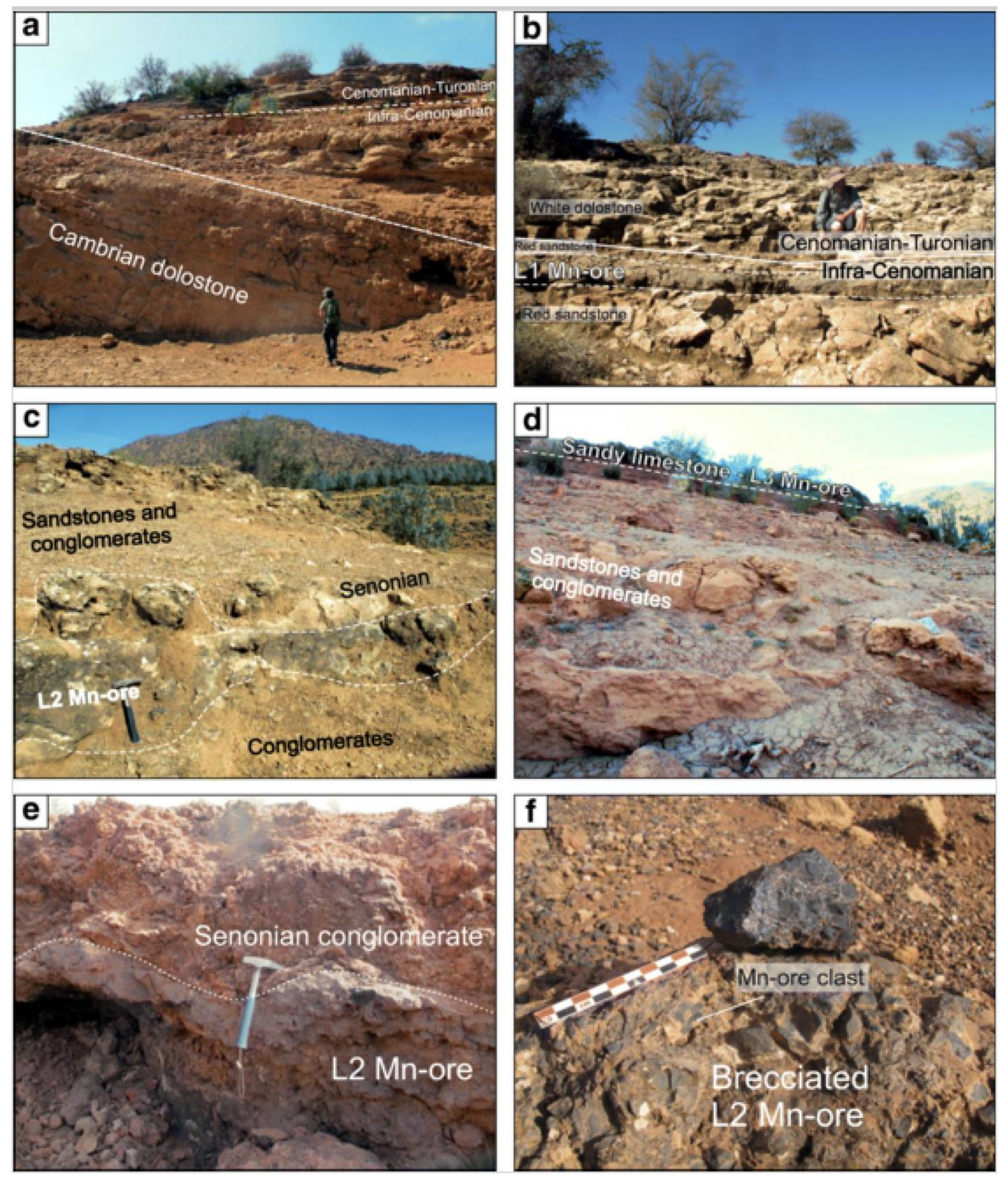


\section{Fig. 4}

Stratigraphic position of the Mn orebodies along a west-east transect showing the stratabound character. Stratigraphic logs are located by stars on the map of the upper right corner

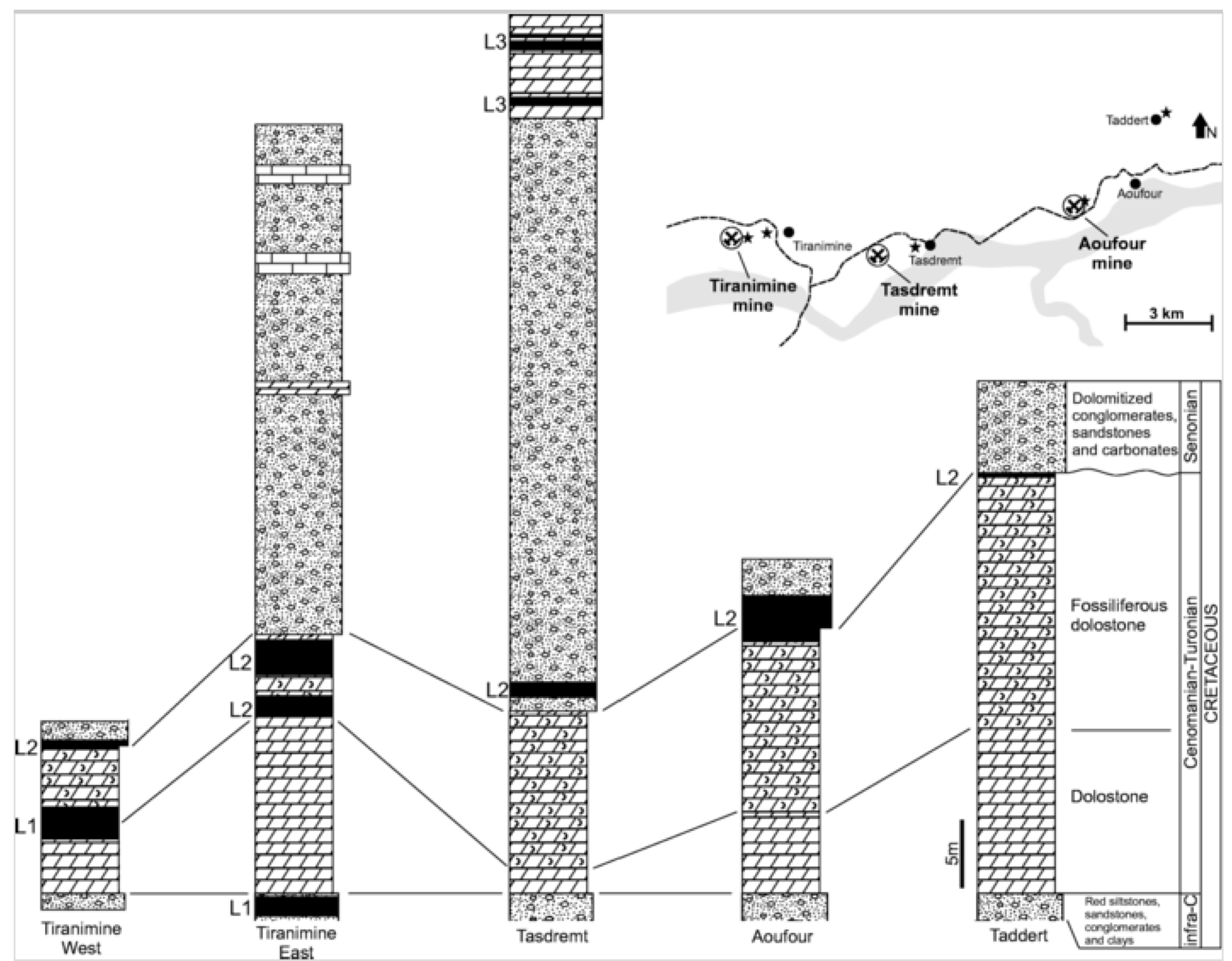


The variable thickness of this whole Cretaceous series is attributed to paleotopographic heights of Cambrian dolostones (Fig. 4). The Eocene red sandstone and marl cover is only present in the western part of the area (Fig. 1c; Ambroggi 1963).

On a local level, Atlasic deformations have been superimposed on the Variscan folding of the Cambrian bedrock and the Mesozoic cover. Cretaceous and Cenozoic rocks were deformed during a post-Cretaceous phase, which has resulted in the formation of (1) the NE-SW Aoufour syncline, (2) the NW-SE anticline in the western part of the Tasdremt area, (3) the thrusting of the Cambrian bedrock over Cretaceous sediments (Fig. 1c), and (4) an angular unconformity of Quaternary sands on top of Cretaceous rocks (Bouladon and Meune 1951; Parizot 2017).

\section{Material and methods}

The Mn levels unevenly occur in an area of about $15 \mathrm{~km}(\mathrm{E}-\mathrm{W})$ and $2 \mathrm{~km}(\mathrm{~N}-\mathrm{S})$, where the CT dolostones crop out (Fig. 1c). The Mn ore progressively disappears to the north. Our investigations focus on three ancient mining sites located in Tiranimine, Tasdremt and Aoufour (Fig. 1c). Small trenches, dry streams and galleries, several meters long, enabled investigation of the orebodies. We have also investigated "unweathered" poorly mineralized distal CT dolostones in Taddert, which are located several kilometers away from the main Mn concentrations (Fig. 1c). From these sampling sites, we have built five stratigraphic logs (Fig. 4) to show the stratigraphic position and the lateral variations of the Mn orbodies. More than one hundred samples were collected from these sites in order to determine the chemical composition, the mineralogy and petrography of ores and host rocks. From these samples, twenty-three geochemical analyses were performed for major and trace elements (Tables 1 and 2; ESM 2 S1). $\mathrm{AQ3}$

\section{Mineralogy and petrography}

Twenty-seven polished sections and twenty-two thin sections were prepared for petrographic analyses. All these samples were analyzed for their mineralogy by XRD. XRD analyses of powdered samples were performed using X-ray Panalytical X'Pert Pro diffractometer and a PHILLIPS PW3710 (CuK $\alpha$ radiation) at the PC2 platform (UNamur), operating at $40 \mathrm{kV}$ and $30 \mathrm{~mA}$. The main mineral phases were identified using the ICDD View software with PDF-2 data base (Powder Diffraction File 2009). Thin and polished sections were studied by optical microscopy and using a JEOL 6010 LV and 
7500-F Scanning Electron Microscopes (SEM) coupled with an ULTRA MINI-CUP Energy Dispersive Spectrometer (EDS) hosted at the Microscopy Service of the University of Namur.

AQ4

\section{Geochemistry}

Geochemical analyses were carried out at Activation Laboratories Ltd. (Tables 1 and 2; ESM 2 S1; Canada). Crushing was performed with a RETSCH PM 100 planetary ball mills (University of Namur). REE and trace elements were analyzed by lithium metaborate/tetraborate fusion Mass Spectrometry (FUS-MS) and major elements by Fusion Inductively Coupled Plasma Optical Emission Spectrometry (FUS-ICP). FeO was quantified by titration. Trace elements Ba, Sc, Be, Sr, Y, Zr and V were determined with FUS-ICP. Gold was measured by Instrumental Neutron Activation Analysis (INAA). The samples were encapsulated and irradiated at a thermal neutron flux of $7 \times 10^{12} \mathrm{ncm}^{-2} \mathrm{~s}^{-1}$. After a 7-day period in order to allow ${ }^{24} \mathrm{Na}$ to decay, the samples were counted on a high purity Ge detector with resolution better than $1.7 \mathrm{KeV}$ for the $1332 \mathrm{KeV}{ }^{60} \mathrm{Co}$ photopeak. Using the flux wires and control standards, the decay-corrected activities were compared with a calibration developed from multiple certified international reference materials. One standard was run for every 11 samples. One blank was analyzed per work order. Duplicates were analyzed when sample material is available (Hoffman 1992). Detection limit for $\mathrm{Au}$ is $2 \mathrm{ppb}$. FUS-ICP, ICP-OES was used to measure $\mathrm{Pb}$ and Mo concentration, after a 4-acid digestion (hydrochloric-nitric-perchloric-hydrofluoric), when values higher than the quantification limits (10,000 ppm and 100 ppm, respectively) were reached.

\section{K-Mn oxide geochronology}

Coronadite group minerals (hollandite supergroup; Biagioni et al. 2013) are the most suitable Mn oxides for ${ }^{40} \mathrm{Ar} /{ }^{39} \mathrm{Ar}$ geochronology, as they can host significant amounts of structural $\mathrm{K}$ mixed with other cations in the tunnel structure (Turner and Buseck 1979; Post 1999). The general formula of this group is $\mathrm{A}^{2+}\left[\mathrm{Mn}^{4+}{ }_{6} \mathrm{Mn}^{3+}{ }_{2}\right] \mathrm{O}_{16}$ or $\mathrm{A}^{+}\left[\mathrm{Mn}^{4+}{ }_{7} \mathrm{Mn}^{3+}\right] \mathrm{O}_{16}$, with $\mathrm{A}=$ $\mathrm{K}, \mathrm{Na}, \mathrm{Pb}, \mathrm{Ba}$ or $\mathrm{Sr}$ (Post 1999; Biagioni et al. 2013), but the composition is often intermediate between the end-members, resulting in variable $\mathrm{K}$ contents. Cryptomelane is the $\mathrm{K}$-bearing end-member of this group. The crystallographic structure ensures retentiveness of the argon and is suitable for ${ }^{40} \mathrm{Ar} /{ }^{39} \mathrm{Ar}$ and K-Ar geochronology (e.g., Vasconcelos et al. 1992 , 
1994; Ruffet et al. 1996; Hénocque et al. 1998; Vasconcelos 1999; Colin et al. 2005; Li et al. 2007; Beauvais et al. 2008;

De Putter et al. 2015).

The selected K-Mn oxide samples show the typical botryoidal and colloform textures forming successive growth bands during mineral precipitation (Fig. 5c) that represents direct precipitation of manganese from mineralizing fluids into open spaces. The poor crystallinity and low purity of mixed Mn oxides have therefore not been considered during the samples selection. Fourteen grains of coronadite group minerals were selected from the three sampling sites: 6 samples from Tasdremt, 4 from Tiranimine, and 4 from Aoufour. One sample is located in the L1 Mn ore level in Tiranimine, twelve samples in the L2 Mn orebody, in the fossiliferous CT dolostones and/or in the Senonian conglomerate, and one sample in the L3 Mn ore level in Senonian dolostone in Tasdremt. All dated materials were hand-picked from crushed rocks, washed in distilled water in an ultrasonic bath, and dried to avoid dust adsorbed on surface grains. The crystallinity, purity and composition were determined by XRD on aliquots of the sample. Several grains from each sample were investigated SEM. Eight of these samples are pure hollandite supergroup minerals, whereas six display quartz, dolomite and calcite inclusions. Such heterogeneous materials were deliberately selected because they represent the best preserved samples for some specific levels (i.e., L3 Mn ore) that did not yield pure K-Mn oxide phases.

\section{Fig. 5}

a Sketch illustrating the relationships between manganese ores, dolostones, sands, and dissolution breccia. Photo locations are shown by white rectangles in Fig. 5a. b Brecciated L2 orebody and its relation with the dissolved dolostone and karst cavities filled by sands in the Aoufour gallery showing location of sample 16AOU15. c Botryoidal Mn oxides (hollandite) on the top of the Tasdremt mine. d Brecciated L2 Mn ore filled by a late calcite cement in the Aoufour gallery. e Karstic lenses in the CT dolostones (Tiranimine) filled with red sands interbedded with reworked Mn oxide blocks. Calcite is late and grows onto sands and Mn oxides. f Relationship between a collapse and dissolution breccia on the top of the CT dolostones. The collapse breccia (with angular fragments of various origins) may be part of the upper detritic series (Senonian?), whereas the dissolution breccia preserves some residues of the CT dolostones. Both breccia are filled with a red sandy matrix. g Fossiliferous dolostone impregnated by Mn oxides (L1?) $2 \mathrm{~m}$ below the L2 level in Tiranimine 


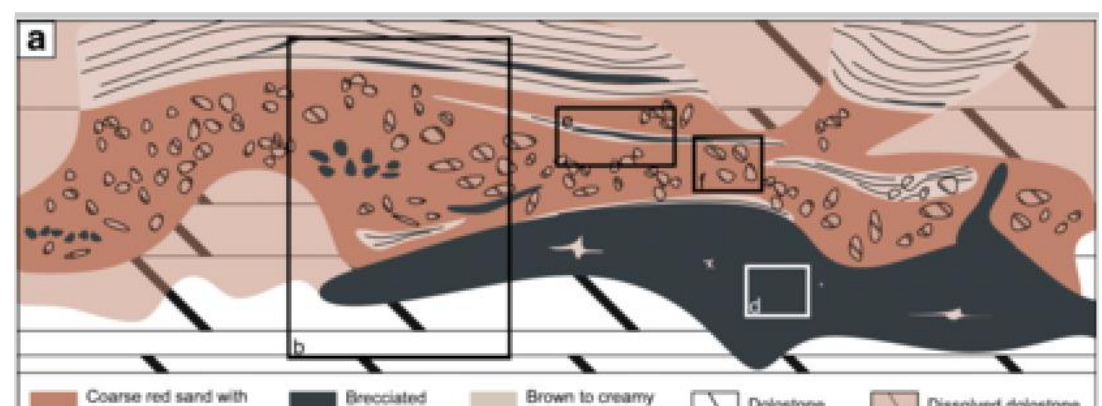

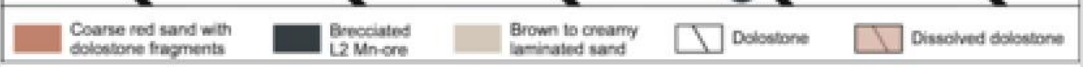
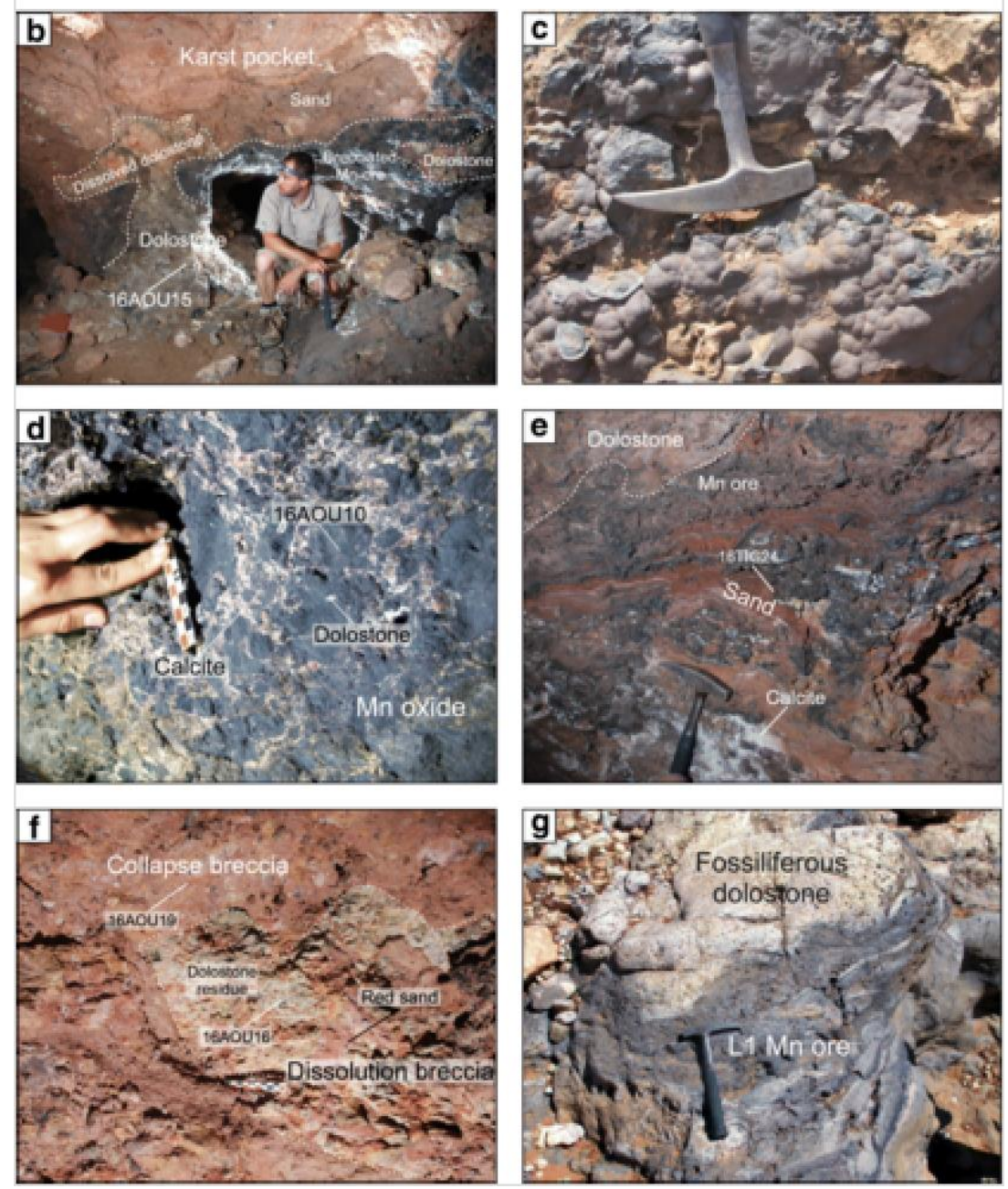
${ }^{40} \mathrm{Ar} /{ }^{39} \mathrm{Ar}$ step-heating analyses were performed with a $\mathrm{CO}_{2}$ laser probe coupled with a MAP 215 mass spectrometer, using the procedure described by Ruffet et al. (1991, 1995, 1996, 1997). Irradiation of samples was performed at McMaster Nuclear Reactor (Canada) in the 8F facility and lasted $66.667 \mathrm{~h}$ with a global efficiency $(\mathrm{J} / \mathrm{h})$ of $9.767 \times 10^{-5} \mathrm{~h}^{-1}$. The irradiation standard is sanidine TCRs (28.608 $\pm 0.033 \mathrm{Ma}$; Renne et al., 1998, 2010 and 2011). Blanks were performed routinely each first or third/fourth run, and were subtracted from the subsequent sample gas fractions. Apparent age errors were plotted at the $1 \sigma$ level. These ages do not include errors on the ${ }^{40} \mathrm{Ar}^{*} /{ }^{39} \mathrm{Ar}_{\mathrm{K}}$ ratio and age of the monitor and decay constants. Plateau ages were calculated if $70 \%$ or more of the ${ }^{39} \mathrm{Ar}_{\mathrm{K}}$ was released in at least three or more contiguous steps that yielded apparent ages within the $1 \sigma$ of the integrated age of the plateau segment. Pseudo-plateau ages were defined with the same criteria if the plateau segment contained less than $70 \%$ of the ${ }^{39}{ }^{3} r_{K}$ released (Cheilletz et al. 1999), such that the amount of ${ }^{39} \mathrm{Ar}_{\mathrm{K}}$ released is not a disqualifying criterion (Fleck et al. 1977). The errors on the ${ }^{40} \mathrm{Ar}^{*} /{ }^{39} \mathrm{Ar}_{\mathrm{K}}$ ratio and age of the monitor and decay constants were included in the final calculation of the errors of the (pseudo-)plateau ages. Analytical data and parameters used for calculations, such as isotopic ratios measured on pure $\mathrm{K}, \mathrm{Ca}$, and $\mathrm{Cl}$ salts; mass discrimination; atmospheric argon ratios; J-parameter; and decay constants are in ESM 2 S2.

AQ5

\section{Results}

\section{Macroscopic features of the Mn ores}

Bouladon and Meune (1951) identified three manganese levels in the Cretaceous succession (Figs. 2 and 4). The first two (L1 and L2) are located at the base and top of the fossiliferous CT dolostone (Fig. 3b-f), whereas the third (L3) is located in the upper detrital Senonian series (Fig. 3d). The manganese ore contains 10-60 wt.\% Mn, and substantial enrichments in $\mathrm{Pb}(1.0-5.0$ wt.\% $\mathrm{Pb}$ ) and $\mathrm{Ba}(1.5-8.2$ wt.\% Ba; Tables 1 and 2). The L1 layer thickness is highly variable, from 0 to $20 \mathrm{~cm}$ thick, depending on the location. This layer can be found at the top of the infra-Cenomanian sands and clays at Tiranimine (Fig. 3b). The L3 orebody is a succession of different layers (5-40 cm thick), which are enclosed in dolostone levels of the siliciclastic Senonian series (Figs. 3d and 4). Both the L1 and L3 orebodies disappear to the north and east (Fig. 4).

The L2 orebody, which is present along the entire district, was the main manganiferous ore (Fig. 4). This layer is $\sim 80 \mathrm{~cm}$ thick in Tiranimine, 30-60 cm in Tasdremt (Fig. 3c), and 20-50 cm in Aoufour (Fig. 3e), whereas only traces are observed 
in the eastern part of the district and toward the north (Bouladon and Meune 1951). The lower boundary of the layer is generally regular, whereas the top is brecciated and reworked within the lowermost Senonian sands (Fig. $5 \mathrm{a}$ and b). The lower and middle parts of the L2 orebody are in place laminated showing yellow dolostone interbedded with Mn oxides. The upper part is progressively enriched in Mn oxides that form massive botryoidal concretions (Fig. 5c) and blocks of Mn oxides containing spots of partially dissolved dolostone nodules (Fig. 5f; Bouladon and Meune 1951). Stratiform layers of cryptocrystalline Mn oxides are located in small pockets made up of clay and sand (Fig. 5 b and e). Such dissolution is noticed in the Aoufour mine, where white dolostone nodules are successively surrounded by a dolomitic red sand, and sand with small blocks of dolostone, the latter being connected to clayey and sandy pockets (Fig. 5f). Taken together, these features characterize a dissolution breccia. The main Mn ore is situated beneath or alongside these breccias (Fig. 5a). In Tasdremt, the enclosing dolostones are porous and fractured (Fig. 5c), and contain clay lenses (Fig. 5e) and calcite or, in rare cases, barite crystals filling geodic cavities (Bouladon and Meune 1951). The most interesting feature of the uppermost part of the L2 layer is, however, the presence of reworked fragments of the host dolostones, Cambrian dolostones, and blocks of botryoidal Mn oxides (Fig. 3f). These blocks are cemented by carbonates (Fig. 5d; calcite), sands or a second generation Mn oxides. Mn oxides also occur beneath the L2 layer in the form of small veinlets and fossil shell pseudomorphs (Fig. 5g). Bouladon and Meune (1951) highlighted that the L2 layer also lies unconformably above Cambrian dolostones. The same dolostones can also be brecciated and filled by Mn oxides at Tiranimine.

The lateral variations in thickness of the three ore layers (Fig. 4) can be significant even at a local scale. For example, L2 and L3 are observed to the east of the Tasdremt mine, whereas L1 and L2 are found a few hundred meters to the west. Such restricted lateral extension of the orebodies is accompanied by changes in the stratigraphic position of the Mn ore (Fig. 4). Their lateral extension as well as variations in their stratigraphic position indicate that these ores are lenses or pockets rather than continuous stratiform orebodies.

\section{Mineralogy and petrography of the host rocks}

The whole Cretaceous sequence (Fig. 2) exhibits proximal marine (CT carbonates) and continental facies (Senonian sandstones, conglomerates and red clays). The shallow marine (supertidal) origin of the CT is demonstrated by preserved fossil shells, quartz, feldspar, and apatite grains (Figs. 5g and 6b). Circular "glaebules" remind sedimentary (anhydrite?) or pedogenic features (Fig. 6b). However, most primary sedimentary features are obliterated by dolomitization, first by a 
micritic dolomite (Fig. 6a; early diagenesis) formed after the deposition of primary carbonates. The porosity was then partially filled by sparitic dolomite crystals (Fig. 6 a and b), occurring simultaneously with a late meteoric alteration, as shown in the Imini area (Force et al. 1986; Rhalmi et al. 2000; Gutzmer et al. 2006; Dekoninck et al. 2016a). Calcite is a late stage infill (Fig. 6a) which cements fragments of the upper Mn breccia (Fig. 5d). In addition, dedolomitization textures are locally observed (Fig. 6 a and c).

\section{Fig. 6}

a Micritic dolomite $\left(\mathrm{Do}_{\mathrm{m}}\right)$ over which sparitic dolomite rhombs $\left(\mathrm{Do}_{\mathrm{s}}\right)$ and hollandite group mineral (Ho) needles grow in open voids (Aoufour mine; CT; 16AOU06). Late calcite (Ca) partly fills the porosity and replaces some dolomite crystals (dedolomitization; white squares). b Glaebules in the coarse sparitic dolomite matrix (Aoufour mine; CT; 16AOU08). c BSE image of dedolomite crystal residues in hollandite matrix (Tasdremt mine; CT; 16TAS29). d BSE image of mineralized levels in dolostone of the upper detritic series (Senonian), showing Mn oxides (Ho) and calcite filling voids of the host rock (Tasdremt) 

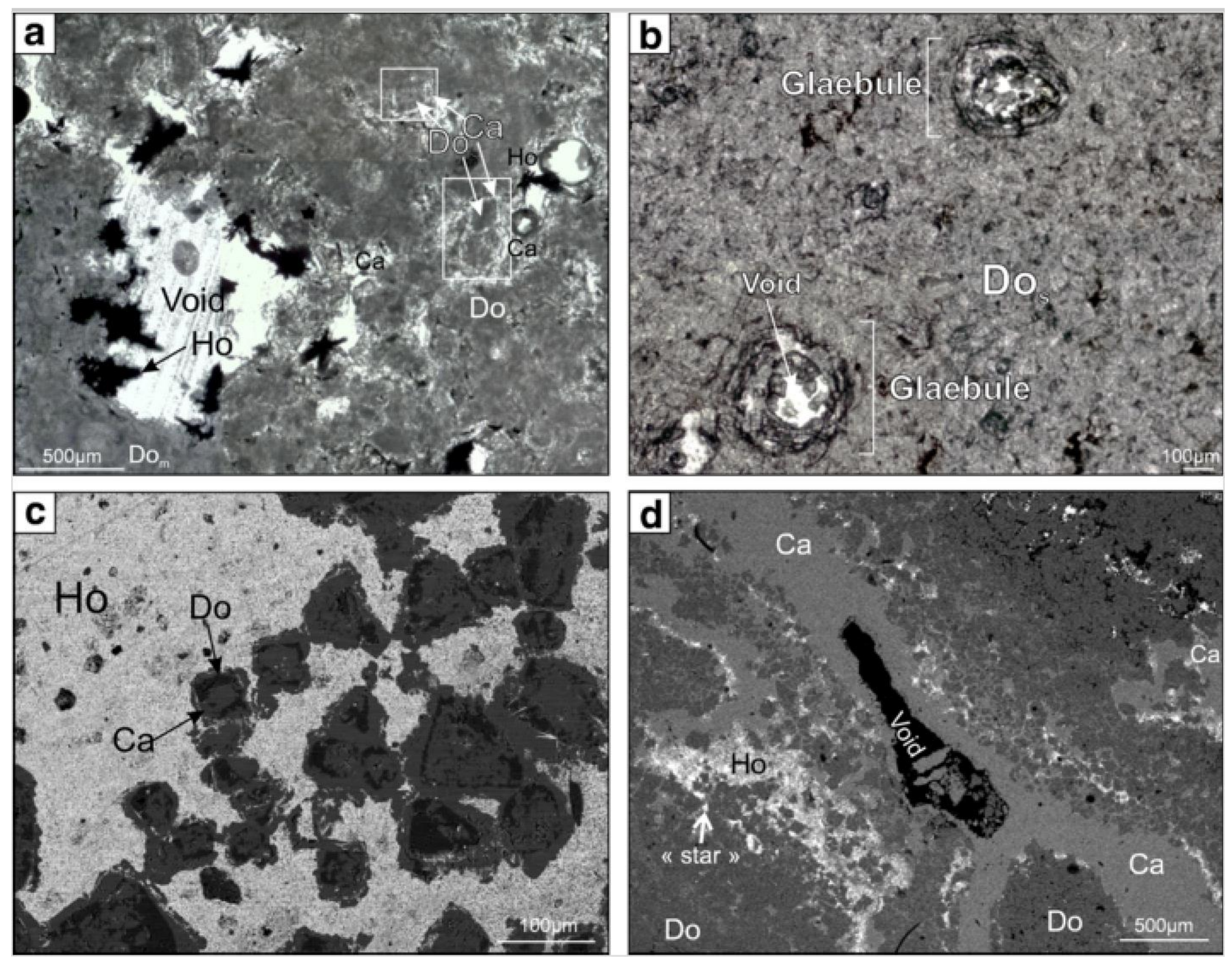

No specific features characterize the dolomitic sandstone and conglomerate of the upper detritic sequence (Late Santonian and Maastrichtian according to Algouti et al. (1999)). They are composed of various fragments originating from the lower CT dolostones or the bedrock, showing variable detrital minerals. Sandy dolostone levels within the upper detritic series 
are intensely dissolved and brecciated. They contain dolomite crystals successively replaced by hollandite and calcite (Fig. 6d).

\section{Mineralogy and petrography of the Mn ores}

The ore-forming minerals are coronadite group (Figs. 5c and 7a), although rare pyrolusite was observed (Bouladon and Meune 1951; Office National des Mines et des Hydrocarbures 2016). Chemical analyses show an intermediate distribution of $\mathrm{Ba}^{2+}, \mathrm{K}^{+}$and $\mathrm{Pb}^{2+}$ between the end-members of the coronadite group minerals (Biagioni et al. 2013): hollandite (Ba), coronadite $(\mathrm{Pb})$ and cryptomelane (K; Tables 1 and 2), respectively. Most samples contain hollandite with subordinate amounts of coronadite, their relative proportion being determined by the concentration of the dominant cation in EDS spectra. The cryptomelane end-member is poorly represented in the Tasdremt ores. The Ba content of these minerals ranges from 3.54 to 15.1 wt.\%, whereas $\mathrm{K}$ ranges from 0 to 3.9 wt.\% and $\mathrm{Pb}$ from 0 to $15.4 \mathrm{wt} \%$. Aluminum and calcium could be present, but $\mathrm{Ca}$ is related to the presence of calcite disseminated between coronadite group crystals (Figs. 6d and 7c). These minerals occur as small needles of 3-100 $\mu \mathrm{m}$ length and 1-10 $\mu \mathrm{m}$ width (Fig. $7 \mathrm{~b}$ and c), as commonly observed in other supergene Mn deposits (Decrée et al. 2010b; Dekoninck et al. 2016a, 2016b, 2019). There are no differences in the composition of the coronadite group minerals according to their position in sandstones and dolostones, which suggests they originate from the same process. Coronadite group minerals are also widely dispersed in the Cretaceous dolostones in the form of small needles between dolomite crystals (Fig. 6d).

\section{Fig. 7}

Petrographic features of the Mn mineralization. a XRD pattern of the three orebodies showing exclusively coronadite group minerals in a dolomite, calcite and/or quartz gangue. b Replacement of dolomite crystals by cryptomelane in the L2 Tasdremt mineralization (16TAS22). c Hollandite partially replacing dolomite crystals with calcite in the L2 Tirnaimine ore (16TIG08). d Brecciated ore characterized by replacement textures and quartz remnants filled with coronadite in the L2 Aoufour ores (16AOU09). e Replacement of lath-shaped crystals (anhydrite or barite) and dolomite in the L1 Tiranimine ores (16TIG31). f Growth bands of hollandite and coronadite (texture 2) overprinting replacement textures of host rock dolostones (texture 1) in the L2 Tasdremt ores (16TAS10). Slight variations in the BSE gray shades are the result of minor changes in the composition of hollandite and coronadite. $\mathrm{g}$

Brecciated hollandite and quartz fragments filled with secondary Mn oxides and calcite in the 
Tiranimine ore (16TIG29). h Gypsum and halite surrounding dolomite crystals within the hollandite matrix in the L1 Tasdremt ore (16TAS37). Ho, hollandite; Cry, cryptomelane; Co, coronadite; Ca, calcite; Q, quartz; Gy, gypsum; Hl, halite 

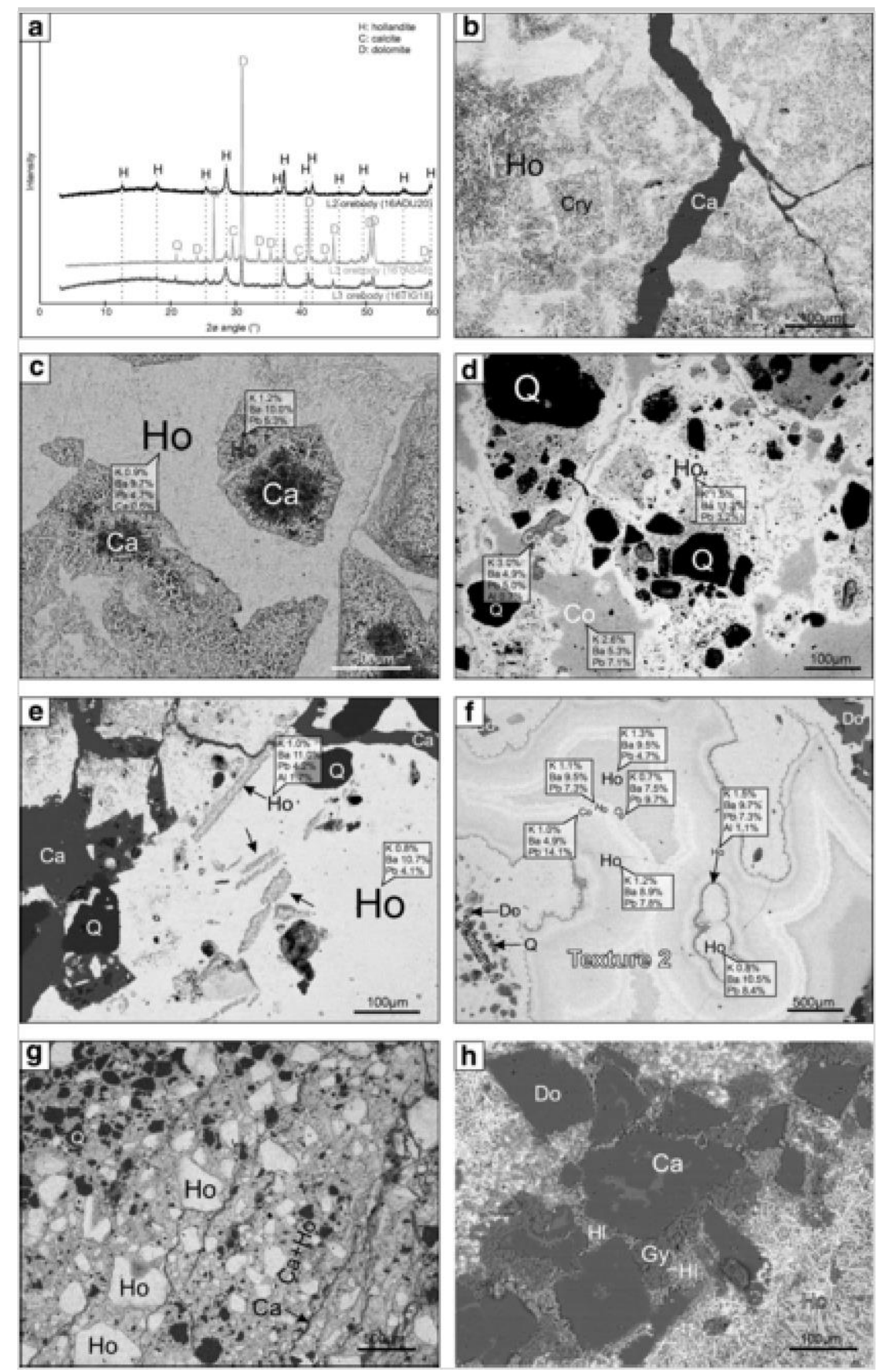
The Tasdremt Mn ores display two different textures. First, epigenetic textures are observed in the core of the Mn orebodies. The dolomite fabric is preserved during replacement by coronadite group minerals (Fig. 7b), but in places coronadite needles grow into rhombohedral cavities, within which calcite occupies the core (Fig. 7c). These features are similar in Senonian dolostone. Coronadite group minerals also preserve the habit of other minerals (Fig. 7e). Colloform aggregates compose the second texture of Mn oxides (Fig. 7f). They are often associated with brecciated zones (Fig. 7g). They grow onto the early replacement texture (Fig. 7f) or directly onto the host rock dolostones (Fig. 5c), sandstones and conglomerates (Fig. 7g). Most of the colloform Mn oxides consist of hollandite (Fig. $7 \mathrm{~d}$ and f), but can also contain rims of coronadite (Fig. 7d). Kaolinite is present within the brecciated and the partially dissolved carbonates.

Both textures are brecciated and cemented by calcite (Fig. 7 b and g). Barite is disseminated in the ore. Gypsum and halite crystals are observed between dolomite crystals (Fig. 7h). Halite grows onto dolomite crystals filled by gypsum/anhydrite crystals. Coronadite group minerals crystallize in the center of sandy lenses.

\section{Geochemistry of the Tasdremt deposit}

Host rock dolostones, sandstones, and conglomerates

The chemical composition of dolostone samples includes variable $\mathrm{SiO}_{2}\left(0.5-9.2\right.$ wt.\% $\left.\mathrm{SiO}_{2}\right)$ and $\mathrm{Al}_{2} \mathrm{O}_{3}(0.2-1.3$ wt.\% $\mathrm{Al}_{2} \mathrm{O}_{3}$ ) contents, depending on the amount of reworked quartz, feldspar, and kaolinite (Table 1). $\mathrm{Fe}_{2} \mathrm{O}_{3}$ content varies between $0.1-1.0$ wt.\%, whereas FeO ranges between 0 and 0.4 wt.\%, further indicating slightly reduced conditions during carbonate deposition. The Mn content is low (0.05-0.13 wt.\% in distal and 0.03-0.29 wt.\% in proximal dolostones; Table 1) even if there are small disseminated Mn oxides within both distal and proximal dolostones. This contamination of the host dolostones is detected by anomalously high $\mathrm{Ba}$ and $\mathrm{Pb}$ (and $\mathrm{Sr}$ ) contents (Tables 1 and 2). Note that Senonian dolostone has a limestone composition due to a late calcite replacement (Fig. 6d).

\section{Manganese ores}

Mn ores contain up to $60 \mathrm{wt} \% \mathrm{Mn}$, but it is often lower, ranging between 11 and $60 \mathrm{wt} . \% \mathrm{Mn}$ (Table 1). Contaminants, such as dolomite, quartz and calcite, yield variable concentrations of $\mathrm{SiO}_{2}(1.3-6.0 \mathrm{wt} . \%), \mathrm{MgO}(0.1-14.0 \mathrm{wt} . \%)$ and $\mathrm{CaO}$ (0.3-28.6 wt.\%). Kaolinite, Fe oxides, feldspar, and phosphates are volumetrically minor or absent, which explains the low 
aluminum, iron and phosphorus contents: 0.2-1.6 wt.\% $\mathrm{Al}_{2} \mathrm{O}_{3}, 0.15-0.84$ wt.\% $\mathrm{Fe}_{2} \mathrm{O}_{3}$ and $0.02-0.23$ wt.\% $\mathrm{P}_{2} \mathrm{O}_{5}$ (Table 1 ). The absence of ferrous iron $(\mathrm{FeO})$ corroborates the oxidation state of the ore. Lead, barium and potassium concentrations are high (Tables 1 and 2; 1.0-4.88 wt.\% Pb, 1.5-8.2 wt.\% Ba, and 0.1-2.5 wt.\% $\mathrm{K}_{2} \mathrm{O}$ ) because of the occurrence of massive coronadite group minerals (Fig. 7). Other metals occur within the Mn oxide tunnel structure: Sr concentrations ranges between 0.04-0.32 wt.\% due to its substitution for $\mathrm{Ba} ; \mathrm{Cu}$ and $\mathrm{Co}$ are also concentrated up to 2390 (140-2390 ppm $\mathrm{Cu}$ ) and 685 ppm (61-685 ppm Co), both being positively correlated with the Mn content (Fig. 8a). The maximum concentration of these metals is in pure hollandite. Conversely, As, Ni and $\mathrm{Zn}$ are not enriched (Table 2). Plotting Pb vs. Zn concentrations in a Nicholson diagram (1992) can discriminate origins of Mn ores. The Tasdremt ores plot in the dubhite field (Fig. 8b), which characterizes oxides formed by weathering of $\mathrm{Pb}-\mathrm{Zn}$ mineralization (Nicholson 1992), very close to the Imini ones. Both ores are distinct from all other groups identified in a Nicholson diagram and define a narrow range within the "dubhite" field.

\section{Fig. 8}

a Plot showing the positive correlation between $\mathrm{Co}, \mathrm{Cu}$, and Mn. b Discrimination plot of Nicholson (1992) showing the Tasdremt ore in the "dubhite" field, close to those of the Imini area (Gutzmer et al. 2006; Dekoninck et al. 2016b) 


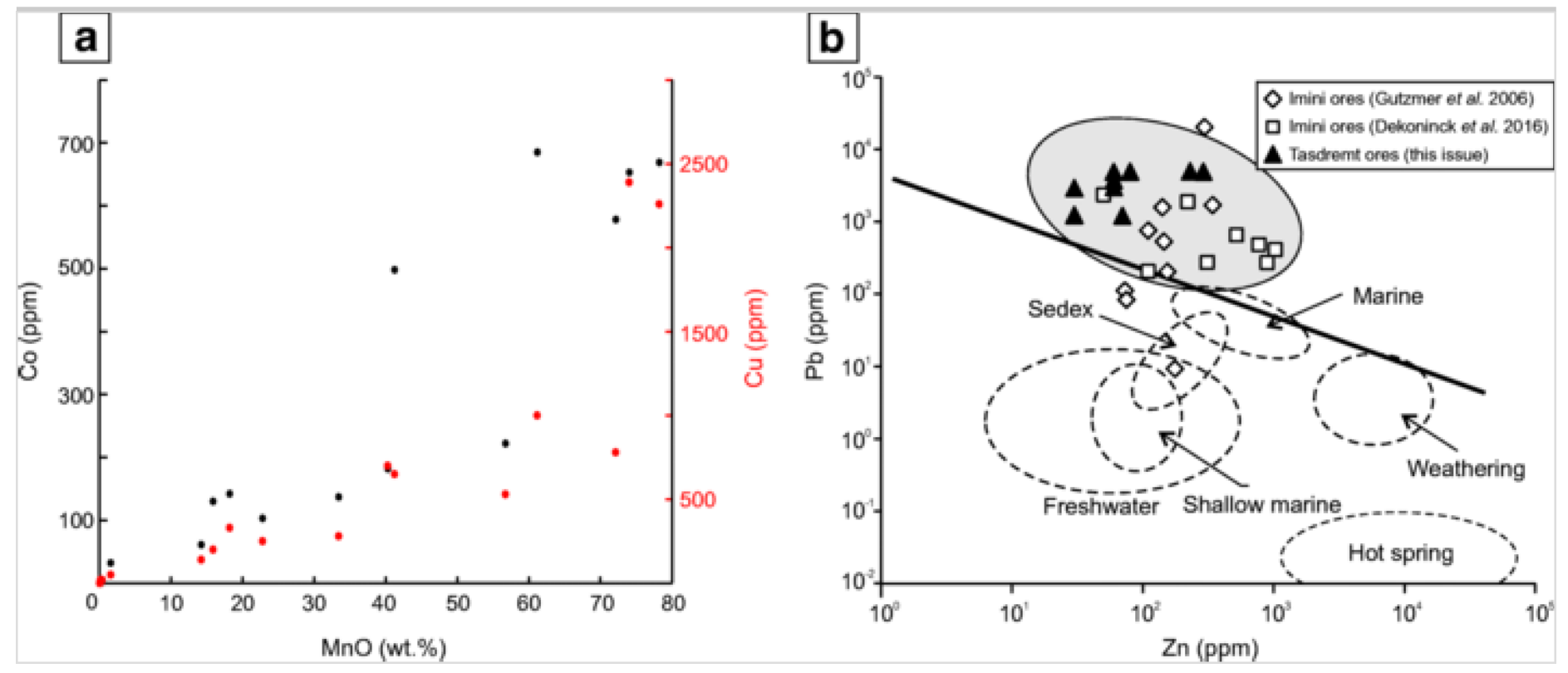

${ }^{40} \mathrm{Ar} /{ }^{39} \mathrm{Ar}$ age spectra of the Tasdremt district

The identification and interpretation of characteristic disturbances of ${ }^{40} \mathrm{Ar} /{ }^{39} \mathrm{Ar}$ age spectra of K-Mn oxides from lateric deposits by Vasconcelos et al. (1995), Ruffet et al. (1996), Hénocque et al. (1998), Vasconcelos (1999), Colin et al. (2005), Beauvais et al. (2008), De Putter et al. (2015), and De Putter and Ruffet (2020) provide a basis for the processing of the ${ }^{40} \mathrm{Ar} /{ }^{39} \mathrm{Ar}$ data. Nevertheless, the crystallization processes of Mn oxides in the karstic domain differ significantly from those in the lateritic domain.

With the exception of four age spectra (Fig. 9 b and c; 16TAS02, 16AOU11, 13 and 17), which display ascending staircase shapes, most spectra show abnormally high apparent ages in the low temperature steps, which rapidly decrease to stabilize in the mid-temperature domain. Samples 16TIG16, 16TAS49 and 16AOU10 (Fig. 9a-c) are less affected by this disturbance in the low temperature steps. This is problematic as it hides information that could be recovered from the low temperature domain, and impedes interpretation of mid- to high temperature steps. Several explanations that are not necessarily exclusive could justify these low temperature high apparent ages. Excess ${ }^{40} \mathrm{Ar}$ is frequently considered to explain such low temperature apparent old ages, but this is not a viable explanation in the supergene environment. The lack 
of a systematic correlation between ${ }^{37} \mathrm{Ar}_{\mathrm{Ca}}{ }^{39} \mathrm{Ar}_{\mathrm{K}}(\# \mathrm{Ca} / \mathrm{K})$ ratios and apparent ages in the low temperature domain does not establish a relationship with degassing of Ca-rich contaminant or inherited components (Fig. 9 a and c; e.g., 16TIG28,

16TAS22). For example, it must be noted that small calcite and dolomite crystals observed in some samples may bring excess $\mathrm{Ca}$. Another explanation to be considered is ${ }^{39} \mathrm{Ar}_{\mathrm{K}}$ loss by recoil during irradiation. This could be related to the degassing of poorly crystallized phases or very small crystals impacted by ${ }^{39} \mathrm{Ar}_{\mathrm{K}}$ recoil during the irradiation in the low temperature domain (Ruffet et al. 1996; Vasconcelos 1999). This could explain some complex trajectories in some experiments in correlation diagrams (Fig. 9 a and c; e.g., 16TIG35 or 16TAS10), suggesting unconventional isotopic shifting.

\section{Fig. 9}

${ }^{40} \mathrm{Ar} /{ }^{39} \mathrm{Ar}$ age spectra and inverse isochron diagrams $\left({ }^{36} \mathrm{Ar} /{ }^{40} \mathrm{Ar}\right.$ vs. ${ }^{39} \mathrm{Ar}_{\mathrm{K}}{ }^{40} \mathrm{Ar}$; Turner 1971; Roddick et al. 1980; Hanes et 1985) with least-squares fitting of the best straight line according to York (1968), York et al. (2004) for a Tiranimine, b Aoufour, and c Tasdremt mines. d Density probability diagram of apparent ages. Plateau and pseudo-plateau ages assumed to be valid are shown in bold. Degassing spectra (16AOU10 and 16AOU17 in 9b) and resizing of age spectra (density probability diagram in 9d) after De Putter et al. (2015) and De Putter and Ruffet (2020). Apparent age error bars are at the $1 \sigma$ level; errors in the J-parameter are not included. Plateau and pseudo-plateau ages ( $1 \sigma$ uncertainties including errors in the J-parameter) are given when applicable. Detailed data set is included in ESM 2 S2. See text for discussion 


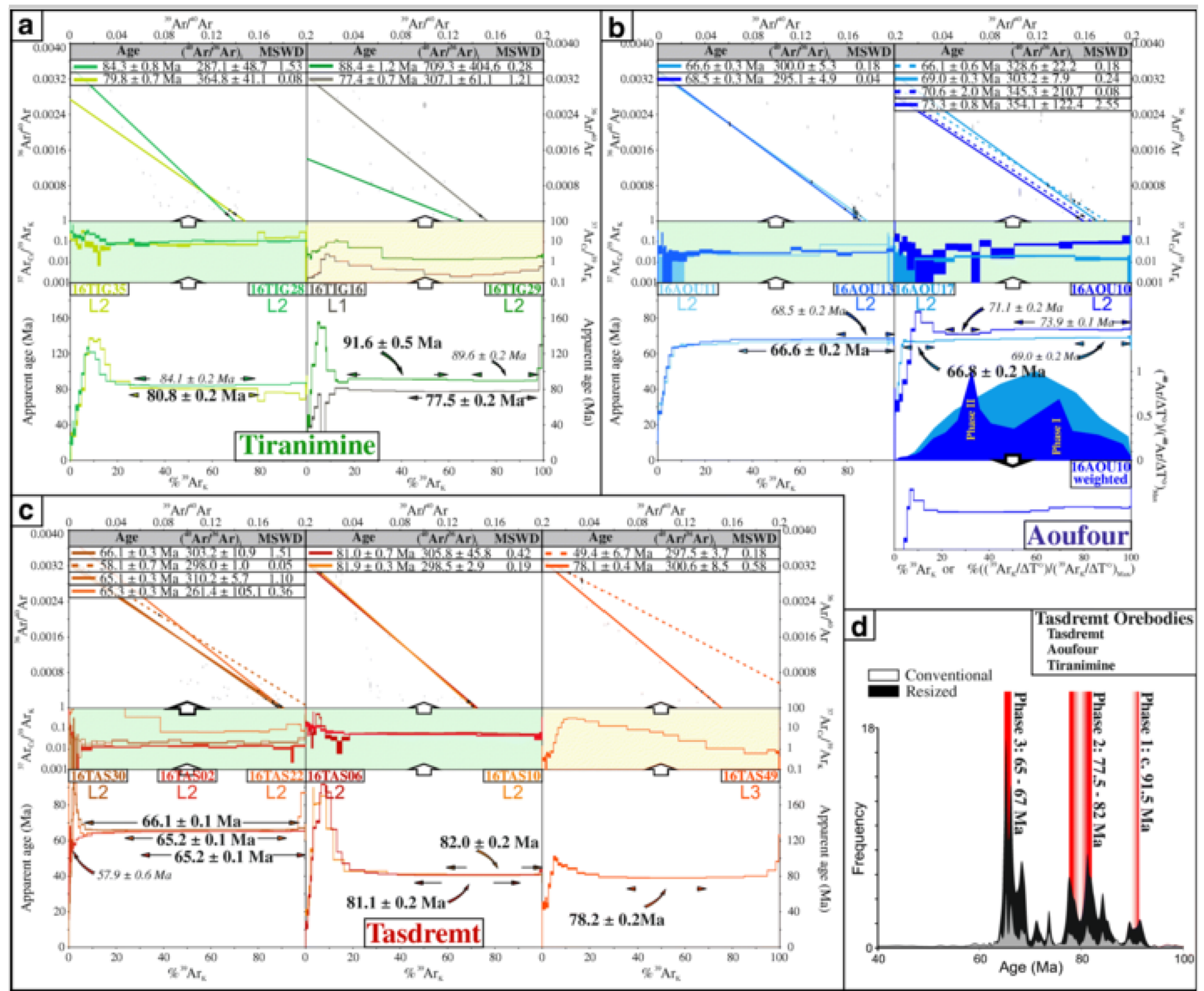

Three ${ }^{40} \mathrm{Ar}^{*} /{ }^{39} \mathrm{Ar}_{\mathrm{K}}$ analyses (16TIG16, 16TIG29 and 16TAS49) are unusual and ambiguous due to the high values of the ${ }^{37} \mathrm{Ar}_{\mathrm{Ca}}{ }^{39} \mathrm{Ar}_{\mathrm{K}}$ ratios, an anomalous feature for Mn oxides (Fig. $9 \mathrm{a}$ and c). Nevertheless, most age spectra in this study 
enable calculation of plateau and pseudo-plateau ages between $65 \mathrm{Ma}$ and $91.5 \mathrm{Ma}$, with substantial clusters of ages in the ranges 65-67 Ma and 77.5-82 Ma (Fig. 9a-c). All results are discussed in detail in the next section on the timing of the Tasdremt Mn ores.

\section{Discussion}

\section{Metal(s) source(s)}

Precambrian Mn deposits are widespread in Africa and constitute one of the main Mn resources in the world (Beukes et al. 2016). Most of the supergene deposits in South Africa (Gutzmer et al. 2012; Vafeas et al. 2018a, b), Central Africa (Decrée et al. 2010a; De Putter et al. 2015, 2018; De Putter and Ruffet 2020), West Africa (Weber 1973; Perseil and Grandin 1978, 1985; Leclerc and Weber 1980; Hénocque et al. 1998; Colin et al. 2005; Beauvais et al. 2008; Dubois et al. 2017), and other African countries (see review by Beukes et al. 2016) derive from the weathering of sedimentary Mn protores. In comparison with lateritic weathering crust Mn deposits, karst accumulations are less common in the geological record of Africa. The most important karst-hosted deposits occur in the $~ 2.0 \mathrm{Ga}$ Postmasburg Manganese Field in South Africa. In Postmasburg, Mn karst-filling deposits are hosted in Precambrian dolostones, where Mn originates from the weathering of an anomalously Mn-rich host rock (Gutzmer and Beukes 1996; Gutzmer et al. 2012; Beukes et al. 2016).

A Gresens mass-balance calculation (Gresens 1967; Grant 1986; Potdevin and Marquer 1987) computed by the EASYGRESGRANT software (López-Moro 2012) indicates that a 28\% volume reduction of the initial stock of the CT dolostones was likely to yield a concentration of $34 \mathrm{wt} \% \mathrm{Mn}$ in the orebodies. These values are based on the average composition of $\mathrm{Mn}$ ores (excluding Mn-rich sand of sample 16AOU19) and distal dolostones (Tables 1 and 2). Th, $\mathrm{Al}_{2} \mathrm{O}_{3}$ and $\mathrm{TiO}_{2}$ were considered immobile elements for volume calculation, and densities of 2.58 and 3.71 were calculated for the host rock and Mn orebodies, respectively. Considering the current thickness of 10-20 m of the mineralized CT dolostones (Fig. 4), a reasonable estimate of the maximum initial thickness of the CT dolostones would be 14-28 m. Consequently, the dissolution of $28 \%$ of the $28 \mathrm{~m}$ thick dolostones $\left(0.16 \mathrm{wt} . \% \mathrm{MnO}_{2}\right)$ would have produced a $0.01 \mathrm{~m}$ thick Mn layer, which is thinner than thickness, reaching $0.8 \mathrm{~m}$, in the L2 orebody. Therefore, the CT dolostones contribution was probably limited in the ore concentration, and external inputs of Mn were needed to reach the current thickness and Mn grade. The relatively high $\mathrm{Pb}, \mathrm{Ba}$, and other trace elements $(\mathrm{Co}, \mathrm{Cu}, \mathrm{As}$, and $\mathrm{V})$ contents in distal dolostones are not very common in carbonates 
(Li 2000), unless dolomitization of the CT carbonates pre-concentred these elements. This would explain the similar Ba/Mn, $\mathrm{Pb} / \mathrm{Mn}$ and $\mathrm{V} / \mathrm{Mn}$ ratio between the Mn ores and distal dolostones (Tables 1 and 2). In addition, the Nicholson diagram (Fig. 8b) clearly shows that the Tasdremt Mn ores belong to the allochthonous deposits field. AQ6

The source of karst-hosted mineralization is not always straightforward since multiple potential parent materials could be involved. A careful approach is therefore needed given that allochthonous inputs necessarily imply the weathering/alteration of voluminous amounts of rocks, originating from the late Cretaceous hinterland. Igneous and volcanic basement rocks are less able to buffer the mineralizing fluids (i.e., feldspars, chlorite) and carbonates are scarce. This is well demonstrated in the Tasdremt deposit where CT dolostones are preferentially mineralized, whereas Cambrian dolostones are poorly or even not mineralized, due to their microcristalline matrix and low porosity. South of the Tasdremt area, the Anti-Atlas was kept buried below a $\sim 1 \mathrm{~km}$ thick sedimentary cover until the middle/late Paleogene (Zouhri et al. 2008; Frizon de Lamotte et al. 2009; Sebti 2011; Ruiz et al. 2011; Leprêtre et al. 2015a), indicating that source rocks mostly derived from the emerged High Atlas to the north. Paleoproterozoic Mn sources, such as those in other African deposits (Beukes et al. 2016), are unlikely given their scarcity in the Tasdremt area bedrocks. However, voluminous volcanic rocks (rhyolite and andesite) hosting numerous $\mathrm{Mn}-\mathrm{Ba}$ and base-metal deposits occur in the Neoproterozoic basement (Bouladon 1948; Westerveld 1951; Bouladon and Jouravsky 1952, 1953; Bouladon et al. 1955; Jouravsky 1958, 1963; Pouit and Jouravsky 1960, 1961, 1962; Jouravsky and Pouit 1963; Pouit 1964, 1966, 1976, 1980; Gaudefroy et al. 1965; Sebbag 1969; Choubert and Faure-Muret 1973; Lippolt and Hautmann 1995; Bouabdellah and Levresse 2016; Bouabdellah et al. 2016). They could therefore have enabled the Tasdremt metal association (Mn, Ba and Pb). Similarly, MVT and other base-metal deposits are widespread in Jurassic rocks in the Atlas belt (i.e., Choulet et al. 2014; Bouabdellah and Sangster 2016; Buatier et al. 2016; Verhaert et al. 2017, 2018) and could act as a potential source of metals, leading to the enrichment, up to several percents in $\mathrm{Pb}$, in Tasdremt (Tables 1 and 2). The enrichment in other metals ( $\mathrm{Cu}$, Mo, As, V, and Zn; Fig. 8 a and b; Table 2) in the Tasdremt area would most likely be inherited from weathering/alteration of hypogene deposits rather than a direct precipitation of these metals from hydrothermal fluids in the Tasdremt karst system. Former extensive Triassic-Jurassic basalts (Central Atlantic Magmatic Province; Verati et al. 2007) in the High Atlas, now mostly eroded, could also be a reasonable source of metals, as they commonly contain up to 0.16 wt.\% Mn (Bensalah et al. 2013). 
The current $\mathrm{Mn}-\mathrm{Ba}-\mathrm{Pb}$ association is not very common in Mn karst-hosted deposits, especially considering that a single variety of minerals hosts these metals (coronadite group; Fig. 7). However, some of these metals are known to be enriched in weathering crust-type Mn deposits (Varentsov 1996; Kuleshov 2016; Beukes et al. 2016). The transport of Mn, Pb and $\mathrm{Ba}$ in low temperature aqueous fluids (meteoric) requires a $\mathrm{pH}$ below 10 and $\mathrm{O}_{2}$-free conditions, with a low sulfur content in order to prevent sulfate (e.g., barite), sulfide (e.g., galena) and carbonate (e.g., cerussite, witherite) precipitation (Hem 1963; Garrels and Christ 1965; Maynard 2014). These features indicate that seawater cannot be involved in the metal transport because significant quantities of sulfur would inhibit the simultaneous transport of $\mathrm{Ba}$ and $\mathrm{Pb}(\mathrm{Gutzmer}$ et al. 2006; Chester and Jickells 2012; Turekian and Holland 2014). The association of karst, cave sediments and Mn oxides strongly supports ore formation during a period of terrestrial exposure. Likewise, fresh meteoric waters cannot easily mobilize $\mathrm{Mn}, \mathrm{Pb}$ and $\mathrm{Ba}$, as the oxidation potential is too high to maintain dissolved $\mathrm{Mn}^{2+}$ in the fluid, unless the temperature and the salinity of the fluid increase (Barnes 1997). Additionally, dissolved organic matters, in particular organic acids, could increase the manganese solubility, owing to low pH (Crerar et al. 1972; Stone and Morgan 1984a, 1984b; Stone 1987; Varentsov 1996). This means that $\mathrm{O}_{2}$-free ground water is the most likely carrier of metals given that they can maintain low oxygen fugacity conditions.

\section{Mineralization process}

The precipitation of Mn oxides in open voids, fractures and pores, originating from carbonate dissolution and karstification (Fig. 5), makes the Tasdremt deposit a karst-hosted Mn accumulation. Geochemical data supports the karst filling and the multistage formation of the Tasdremt Mn ores (Fig. 8b). Ore-forming processes are similar between the three Mn levels, with multistage post-sedimentation mineralization (Figs. 7 and 9), and are identical to the processes described by Dekoninck et al. (2016a) in the C3 orebody of the Imini deposits: Mn oxides replaced the dolostone fabric (Fig. 7b-e), and, after brecciation, precipitated colloform aggregates (Fig. 7e-g). Brecciation resulted from multiple events and were cemented by late calcite (Figs. 5d, 7b, g, and 10). Dedolomitization textures (Fig. 6a-d) corroborate the meteoric origin of calcite (Ayora et al. 1998; Dewaide et al. 2014).

\section{Fig. 10}


Chronology of Tasdremt manganese ores illustrating that Mn oxides precipitated in three phases at $\sim 91.5$ Ma (phase 1), 75 \&Ma (phase 2), and likely at 65-67 Ma (phase 3). Sedimentation periods in the Tasdremt area are based on Ambroggi and Algouti et al. (1999)

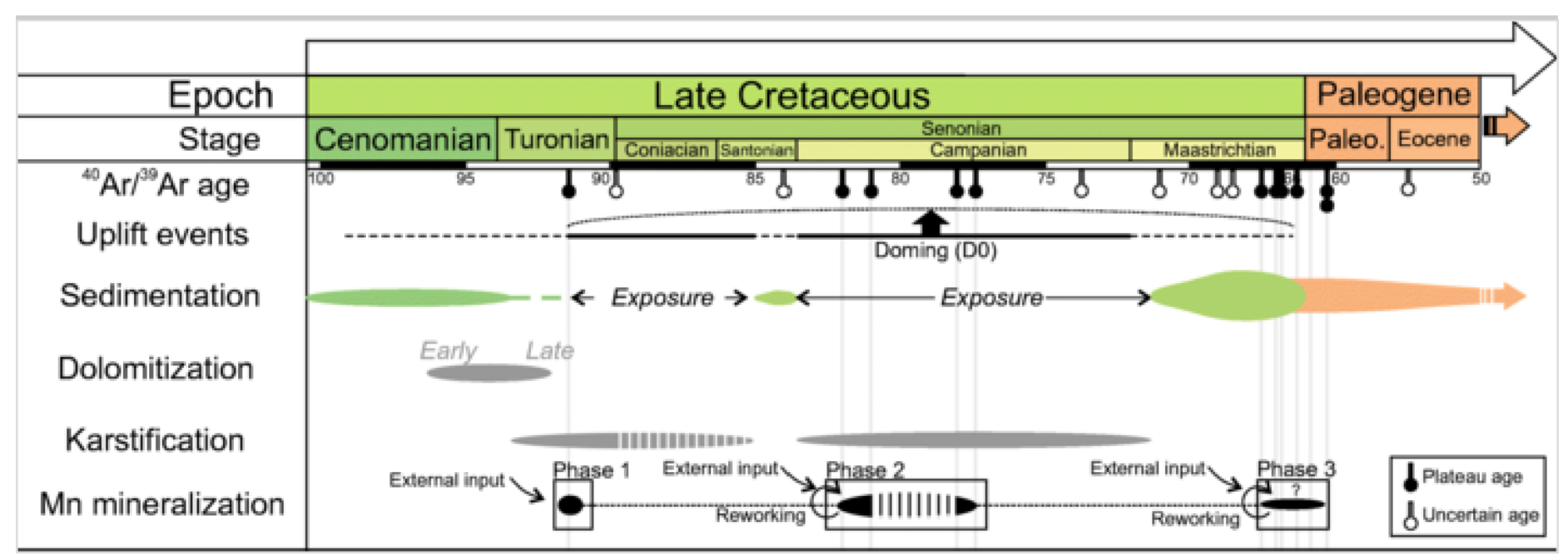

The chemical oxidation of dissolved $\mathrm{Mn}^{2+}$ (and $\mathrm{Mn}^{3+}$ ) is usually the main controlling parameter leading to the formation of $\mathrm{Mn}^{4+}$-oxyhydroxides, and karst systems provide the oxidation potential for manganese mineralization (e.g., Varentsov 1996; Gutzmer et al. 2006, 2012; Dekoninck et al. 2016a, 2016b). The subsequent enrichment is also enhanced by surface autocatalytic effects, which are responsible for the growth bands. Such colloform aggregates also accommodate other cations from solutions (Ba, K, Pb, Na, Co, Cu, Ni; Burns and Burns 1979; Hénocque et al. 1998; Post 1999; Vasconcelos 1999). However, the high oxidation potential of the depositional environment did not act as a single driver for the formation of massive Mn oxide layers. The ore-forming processes are intimately related to carbonate dissolution. Dolomite breakdown and related karstic features (Fig. 5) indicate that meteoric fluids were buffered, leading to a rapid rise in pH, and followed by precipitation of Mn oxides. The mix of two saturated carbonate solutions with different $\mathrm{CO}_{2}$ concentrations may give rise to karstification (Dreybrodt 1988; Corbella et al. 2003) accompanying ore formation. The metal-bearing $\mathrm{O}_{2}$-free groundwater was likely mixed with $\mathrm{O}_{2}$-rich surficial waters, similar to the scenario proposed by Gutzmer et al. (2006) for the Imini deposits. 


\section{Timing of the Tasdremt Mn ores}

The plateau and pseudo-plateau age dispersions (91.5-65 Ma; Figs. 9 and 10) and the age spectra shapes suggest that the Tasdremt ores formed in 3 phases, c. $91.5 \mathrm{Ma}, 82-77.5 \mathrm{Ma}$, and 67-65 Ma. The age spectra yielded by samples 16AOU17 and 16AOU10 (Fig. 9b) illustrate the sequence of the two most recent phases. Apart from the low temperature steps $(<4 \%)$, the progressive increase of apparent ages shown by the 16AOU17 (Fig. 9b) age spectrum indicates that a component older than c. $69 \mathrm{Ma}$ was disturbed during an event at least as young as c. $66.8 \mathrm{Ma}$. Its degassing spectrum does not show any specific degassing peak, which does not allow to establish a link with a specific crystalline component. The broadly similar shape of the 16AOU10 age spectrum also points to a disturbance of a component as old as c. 74 Ma during an event younger than c. $71 \mathrm{Ma}$. In this case, the degassing spectrum identifies two distinct phases, which suggests the coexistence of two distinct crystalline components within analyzed single grain (Fig. 9b). The weighting of the 16AOU10 age spectrum shows that this disturbing component, which is amplified by a factor of 2.7 (c. $40 \%$ of the weighted spectrum versus c. $14 \%$ of the conventional spectrum), is substantial. Despite an imperfect dissociation of components, experiments 16AOU10 and 16AOU17 tell a similar story but with varying degrees of disturbance. The disturbance highlighted by these two experiments is probably associated with the event identified by the plateau and pseudo-plateau ages in the range 65.266.6 Ma yielded by samples 16TAS02, 22 and 30 (Fig. 9c), and 16AOU11 (Fig. 9b). This event, at the Cretaceous/Paleocene boundary, referred to as "phase 3," is common in the set of samples (Figs. 9d and 10). It appears to be of variable intensity and it is expressed in different ways, rarely through neocrystallisation of a new mineral (e.g., 16AOU10), much more frequently through partial (16AOU17 or 16AOU13) or complete (16AOU11) recrystallization of a pre-existing phase. It seems less intense in Aoufour than in Tasdremt where it constitutes the only component in three samples (16TAS02, 22 and 30). By contrast it is absent, or not detected, in Tiranimine.

Phase 2 is as old as $\sim 74 \mathrm{Ma}$ as suggested by a pseudo-plateau in the high temperature steps of experiment 16AOU10 (Fig. $9 b$ ). This phase 2 is characterized by plateau and pseudo-plateau ages in the range of 77.5-82.0 Ma in samples 16TAS06, 16TAS10, 16TAS49, 16TIG16 and 16TIG35 (Fig. $9 \mathrm{a}$ and c). With the exception of samples 16TAS49 and 16TIG16, the mineral components associated with phases 2 and 3 also differ in their calculated ${ }^{37} \mathrm{Ar}_{\mathrm{Ca}}{ }^{39} \mathrm{Ar}_{\mathrm{K}}$ ratios (\#Ca/K), at c. 0.010.02 and c. $0.05-0.06$ respectively. This difference is also observed in experiment 16AOU10, which registered both phases with a positive correlation between apparent ages and ${ }^{37} \mathrm{Ar}_{\mathrm{Ca}}{ }^{39} \mathrm{Ar}_{\mathrm{K}}$ ratios, both increasing from low to high temperature 
steps (Fig. 9b). These decreasing ${ }^{37} \mathrm{Ar}_{\mathrm{Ca}}{ }^{39} \mathrm{Ar}_{\mathrm{K}}$ ratios from phase 2 to phase 3 probably relate to an increase in the $\mathrm{K}$ content of the mineral component which characterizes phase 3 .

Three ${ }^{40} \mathrm{Ar}^{*} /{ }^{39} \mathrm{Ar}_{\mathrm{K}}$ analyses (16TIG16, 16TIG29 and 16TAS49) yield unusual high ${ }^{37} \mathrm{Ar}_{\mathrm{Ca}}{ }^{39} \mathrm{Ar}_{\mathrm{K}}$ ratios for the coronadite group minerals (Fig. 9 a and c). Their ${ }^{37} \mathrm{Ar}_{\mathrm{Ca}}{ }^{39} \mathrm{Ar}_{\mathrm{K}}$ spectra (Fig. 9 a and c) show that the whole degassing domain is involved, even if the overall values decrease by a factor of 10 from the low to high temperature steps. Coronadite group minerals are not expected to incorporate significant amounts of $\mathrm{Ca}$ in their crystalline structure and no Ca-bearing $\mathrm{Mn}$ oxides, such as birnessite or todorokite, have been detected in samples from the Tasdremt orebodies, such that the analyzed KMn oxide samples cannot generate such high ${ }^{37} \mathrm{Ar}_{\mathrm{Ca}}{ }^{39} \mathrm{Ar}_{\mathrm{K}}$ values. These results suggest older apparent ages and correlate the higher the $\mathrm{Ca} / \mathrm{K}$ ratios. If only intermediate to high temperature domains are considered - leaving out the apparent high ages of the low temperature domain -, sample 16TIG29 yields the oldest apparent ages (c. 91.5 Ma), which is concomitant with the highest ${ }^{37} \mathrm{Ar}_{\mathrm{Ca}}{ }^{39} \mathrm{Ar}_{\mathrm{K}}$ ratios $(1.4-1.7$; Fig. 9a). This correlation seems to be confirmed by the analysis of sample 16TIG16, whose apparent ages (77.5-78.5 Ma) and ${ }^{37} \mathrm{Ar}_{\mathrm{Ca}}{ }^{39} \mathrm{Ar}_{\mathrm{K}}$ ratios $(0.2-1.1)$ are both significantly lower (Fig. 9a). However, this correlation is not found in $16 \mathrm{TAS} 49$, with apparent ages around $78-79 \mathrm{Ma}$, and ${ }^{37} \mathrm{Ar}_{\mathrm{Ca}}{ }^{39} \mathrm{Ar}_{\mathrm{K}}$ ratios decrease from c. 13 to c. 0.6 (Fig. 9c). Dolomite was identified in samples 16TIG29 and 16TAS49, which is consistent with their measured ${ }^{37} \mathrm{Ar}_{\mathrm{Ca}}{ }^{39} \mathrm{Ar}_{\mathrm{K}}$ ratios. It is therefore reasonable to assume that the analyzed grain from sample 16TIG16 also contained dolomite, although it was not detected by SEM-EDX. In contrast, dolomite was observed in 16TAS06, but the ${ }^{37} \mathrm{Ar}_{\mathrm{Ca}}{ }^{39} \mathrm{Ar}_{\mathrm{K}}$ ratio was not affected. The presence of dolomite would attest to an initial mineralization phase at c. $91.5 \mathrm{Ma}$ (phase 1). This initial Late Turonian mineralization is poorly preserved in other samples because it was likely almost totally erased by the main Campanian phase (phase 2). This is demonstrated by two saddle-shaped age spectra of samples 16TIG29 and 16TIG28, with saddle basements at c. 89.6 Ma and c. 84.1 Ma. They express, two stages of partial recrystallization of Late Turonian mineralization during Campanian (phase 2). Phase 2 could have lasted from c. $82 \mathrm{Ma}$ dow to c. $77.5 \mathrm{Ma}$, perhaps intermittently.

This set of analysis contrasts with the analyses of K-Mn oxides that crystallize in a strictly supergene domain as observed in lateritic weathering profiles (e.g., Hénocque et al. 1998; Colin et al. 2005; Beauvais et al. 2008; De Putter et al. 2015; De Putter and Ruffet 2020). At surface pressure and temperature, K-Mn oxides are stable, which does not facilitate a substantial remobilization of Mn. Mn oxides most frequently grow through the coalescence of successive generations often 
with partial or total preservation of the oldest phase. Such growth process results in intricate samples composed of mixed Mn oxide generations, in which the oldest component often remains detectable (e.g., De Putter and Ruffet 2020). There is almost no such evidence in the present study since only sample 16AOU10 clearly suggests the coexistence of two mineral phases. To a lesser extent, the slightly increasing age spectra of 16AOU13 and 16AOU17 (Fig. 9b) could also indicate such coexistence. But overall, the successive events that have shaped mineralization in the Tasdremt district most often resulted in the complete replacement of previously crystallized mineral phases.. These observations likely suggest that the phenomena that contributed to the Tasdremt deposit formation were quite different from those occurring in the lateritic weathering profiles, probably due to different environmental factors: temperature, Eh, $\mathrm{pH}$, origin and composition of fluids, direction of propagation of fluids (per descendum, per ascendum, lateral...).

\section{Timing of sedimentation, weathering, karstification, and mineralization}

Reworked blocks of Mn oxides trapped between the CT dolostones and the upper Senonian detritic series suggest a late Cretaceous age for the Mn mineralization (Bouladon and Meune 1951). The Tasdremt area is located relatively close to the late Cretaceous paleoshoreline. The CT dolostones were exposed to weathering agents after withdrawal of the CT sea (Froitzheim 1984; Froitzheim et al. 1988; Thein 1990; Rhalmi et al. 1997, 2000; Frizon de Lamotte et al. 2009), most probably due to a pre-Senonian incipient tectonic phase that caused the emersion of North Africa (Algouti et al. 1999; Frizon de Lamotte et al. 2009; Leprêtre et al. 2018). Algouti et al. (1999) detailed the sedimentary evolution of the Senonian series in an area spreading over the western High Atlas, from Agadir (west) to Imini (east). The sector from Tasdremt to Imini was an emerged land until the late Santonian (Fig. 1 a and b), when marine incursions sporadically deposited sediments (Fig. 10). Two erosion surfaces have been identified within this sedimentary episode ( $\sim 55 \mathrm{~m}$ thick), showing that the emersion of the sector was widespread. The Tasdremt-Imini area remained exposed to meteoric waters during the whole Campanian, likely due to tectonic movements delimited by an angular unconformity at the SantonianCampanian boundary, further west. Despite an erosion phase in the earliest Maastrichtian, $\sim 25 \mathrm{~m}$ thick sediments accumulated during the whole Maastrichtian (Fig. 10). In summary, the Tasdremt sector was above sea level during at least two periods: (i) Coniacian (or possibly Late Turonian) to Early Santonian, and (ii) Campanian to the earliest Maastrichtian. Other periods might however have allowed exposure during the main sedimentary pulses (Algouti et al. 1999). It is worth mentioning that the landscape was significantly different from the current relief, and was most probably at a low elevation, i.e., a few meters above sea level (Algouti et al. 1999). A consequence of this low altitude would have been the poor 
denudation of the $\sim 10-20$ m thick CT dolostone that stabilized the Coniacian-Early Santonian paleosurface, where karstic processes would have from Late Santonian to the Maastrichtian. It is however possible that most of the Turonian disappeared considering the absence of the cherty dolostone (Rhalmi et al. 2000).

Mn mineralization probably started early in the post-sedimentary history of the CT dolostones, after dolomitization in the Tasdremt area. The first precipitation of Mn took place at c. 91.5 Ma (Fig. 9 a and d), prior to deposition of Late Santonian sediments (Fig. 10). This allows for Mn ores to be reworked along the pre-Late Santonian erosion surface, and for detrital Mn oxide grains in karst sediments (Fig. 3c-f). Therefore, the main mineralization phase at $\sim 77.5-82 \mathrm{Ma}$ took place under tens of meters of Santonian sediments during the Campanian exposure episode (Fig. 10). The c. 82 Ma age in the lowermost part of the Senonian series in Tasdremt (L2 level) indirectly supports the hypothesis of Mn formation under cover, given that Mn oxides impregnate "Senonian" sandstones (Fig. 9). This implies that the lowermost part of the socalled "Senonian upper detritic series" is older than c. 82 Ma (Fig. 10).

Karstification probably operated as early as the first Mn mineralization during late Cretaceous exposure periods. Dissolution leading to karst formation was particularly active during the Senonian (Froitzheim et al. 1988), but must have also operated during Cenozoic times, given that some K-Mn oxides, dated at $\sim 65-67 \mathrm{Ma}$, are reworked within karstic-like sediments (Fig. 5). Some brecciation (related to karstification?) events in the L2 ore level postdate the latest phase of ore formation, and could be assigned to undated post-Cretaceous remobilization. Mineralization did not continue through Paleogene times. Several factors could be invoked, such as changes in fluid composition, which was unable to transport manganese and associated metals, changes or depletion of the Mn source(s), or modifications of the mineralizing fluid flow paths as a consequence of later tectonic events.

\section{Metallogenic model}

In light of the previous discussion, the formation of the Tasdremt ores can be summarized in three steps (Fig. 11): (1) early mineralization during the late Turonian (phase 1 at $\sim 91.5 \mathrm{Ma}$ ), (2) a main ore phase between c. 77.5-82 Ma (phase 2), and (3) a mineralization/remobilization phase at c. 65-67 Ma (phase 3).

\section{Fig. 11}


Metallogenic model showing regional and local Mn oxide enrichment related to weathering/alteration and erosion of the late

Cretaceous hinterland. SAF, South Atlasic Front; AAMF, Anti-Atlas Major Fault 

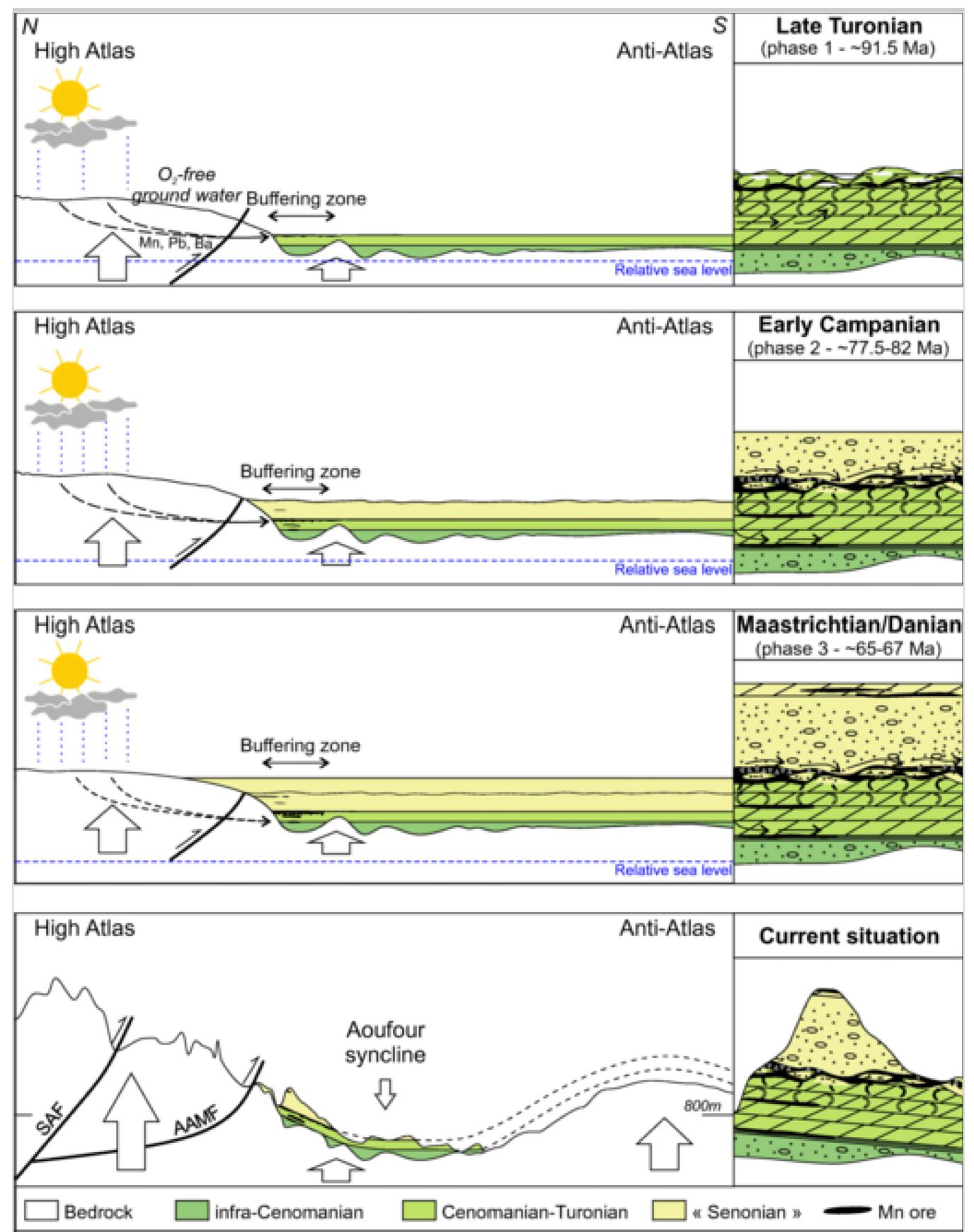
(1) The early mineralization (phase 1) took place rapidly after sedimentation and dolomitization of Cenomanian-Turonian carbonates. After their formation lasting from late Turonian to Early Santonian. These rocks were then exposed to meteoric waters leading to partial dissolution of dolostones and formation of karst cavities. Karstification was facilitated by regional doming of the Atlas belt (Algouti et al. 1999; Frizon de Lamotte et al. 2009; Leprêtre et al. 2018). Early Atlas tectonics movements are suggested during the late Cretaceous period (Bouladon and Meune 1951; Froitzheim 1984; Herbig 1988; Herbig and Trappe 1994; Algouti et al. 1999; Charrière et al. 2009; Frizon de Lamotte et al. 2009; Leprêtre et al. 2018), which has accounted for the late Cretaceous relief creation in the Tasdremt area. This relief did not reach the maximum Late Eocene and current elevation of the Atlas. At the same time, $\mathrm{O}_{2}$-free ground water originating from the late TuronianSantonian hinterland to the north, percolated toward CT dolostones, which consequently acted as an efficient trap for mineralizing fluids. It is unlikely that these fluids were buffered beforehand. The $\mathrm{O}_{2}$-rich environment of the high porosity dolostones and the increase in $\mathrm{pH}$ conditions caused by dolomite dissolution induced precipitation of Mn oxide ores.

(2) No major input of Mn occurred before the first main ore formation phase at c. $77.5-82 \mathrm{Ma}$. The ore-forming process remains the same as for the early mineralization, but under a cover of Late Santonian sediments (Fig. 11). The boundary with the underlying CT dolostones acted as a drain for fluids and allowed Mn ores formation within the lowermost Upper Santonian dolomitized sandstones. The rage of the main mineralization phase, around c. 77.5-82 Ma (Fig. 9d), might be related to pulses of the early Atlas tectonic events or to the Early Campanian climate that would have provided meteoric water from the hinterland and therefore the amount of metals carried to the Tasdremt deposition site.

(3) The last mineralization or reworking phase (phase 3) took place at the Maastrichtian/Danian boundary ( 65-67 Ma), when Maastrichtian sedimentation temporarily ceased, and resulted in new Mn mineralization or most likely remobilization of the previous former ore.

\section{Comparison of Tasdremt to the Imini deposit}

Although the Tasdremt Mn ore has lower grades (42-45\% Mn; Bouladon and Meune 1951) than the Imini mineralization ( $>60 \%$ Mn; Mouttaqi et al. 2011), several parameters are comparable: (1) the occurrence of stratabound orebodies; (2) the mineralogy dominated by coronadite group minerals in the C3 Imini orebed; (3) the development of karst and dissolution figures in association with the formation of Mn oxides (karst-hosted deposit; Fig. 5); (4) the textures of the ore (Fig. 7), 
and (5) the similar geochemical composition (Fig. 8b; Gutzmer et al. 2006; Dekoninck et al. 2016a, 2016b). Therefore, the Tasdremt metallogenetic model could be applied to the analogous Imini ores, at least for the C3 level (Dekoninck et al. 2016a). A difference between these deposits is the scarcity of massive pyrolusite in the Tasdremt deposit, unlike the strong enrichment in Imini. Most of the pyrolusite in the Imini deposits occurs after coronadite group minerals (Dekoninck et al. 2016a) and is restricted to two orebodies C1-C2, absent at Tasdremt. Therefore, the genesis of the pyrolusite-bearing C1C2 orebodies in the Imini deposits likely follow a process different from the Tasdremt mineralization, i.e., during the Tertiary evolution of the area. Composition of the mineralizing fluid is important and would lack $\mathrm{Ba}, \mathrm{Pb}$ and $\mathrm{K}$ in Tasdremt to precipitate cation-free Mn oxides, such as pyrolusite. This together with a higher Pb content and the relatively thin and discontinuous character of the orebodies lower the economic viability of the Tasdremt mineralization. Consequently, it is likely that the C3 level of Imini formed during the same time as the L2 Mn orebody in Tasdremt.

All these features suggest that the Tasdremt deposit is a lateral equivalent of the C3 Imini orebody leading to propose a unique Imini-Tasdremt district of about $100 \mathrm{~km}$-wide, following the south Atlasic front (Fig. 1b). The central connection of this mineralized belt has been nearly eroded by the Cenozoic uplift of the Siroua plateau (Fig. 1b), preserving only few spots of Mn enrichments within Cretaceous series between Imini and Tasdremt (Fig. 1b; Bouladon and Jouravsky 1952; Gresse et al. 2000; Thomas et al. 2000). These Mn ores could also be extended to the whole Atlas belt since similar karsthosted Mn deposits occur in Cenomanian-Turonian carbonates of Tunisia (Jebel Aziza, Gattar Member; Amouri et al. 1991; Ghanmi and Potfaj 1991; Garnit et al. 2020).

\section{Conclusion}

The mineralogy, petrology, geochemistry and field investigations of the Tasdremt Mn mineralization strengthen their genetic link with the C3 Imini orebody. The formation of this relatively discontinuous level in an area spreading over $\sim 100$ $\mathrm{km}$ constrains the processes responsible for these Cretaceous karst-hosted Mn deposits. Even if the source of Mn remains hypothetical between Precambrian volcanic rocks hosting Mn veins, Triassic basalts, MVT in Jurassic rocks, the Cretaceous Atlas hinterland is most likely the source from which metals were carried in $\mathrm{O}_{2}$-free ground water. The location of the $\mathrm{Mn}$ mineralization in the $\sim 10-20 \mathrm{~m}$ thick Cenomanian-Turonian dolostone is linked to the joint increase of $\mathrm{pH}$ and $\mathrm{Eh}$, where the high porosity of dolostone facilitated fluid percolation and/or mixing with shallow $\mathrm{O}_{2}$-rich meteoric water.

The late Cretaceous evolution of the area seems closely associated with the early Atlas geodynamic evolution that led the 
Imini-Tasdremt district to form a high ground delimited to the west and east by sedimentary basins, and for the repeated exposure of the Imini-Tasdremt area to meteoric water in low stand reliefs. K-Mn oxide ages would reflect ground water infiltration pulses. Mineralization and karstification formed mostly during three phases at c. $\sim 91.5 \mathrm{Ma}$, c. $77.5-82 \mathrm{Ma}$, and

c. 65-67 Ma. This termination at the Mesozoic/Cenozoic boundary calls into question the role of the Cenozoic Atlas orogenic build up that would have prevented some other mineralization, denuded some parts of the Mn ores, or limited availability. These processes emphasize the regional extension of the late Cretaceous karst-hosted deposits.

\section{Publisher's note}

Springer Nature remains neutral with regard to jurisdictional claims in published maps and institutional affiliations.

\section{Acknowledgments}

We are grateful to the "Office National des Mines et des Hydrocarbures" (ONHYM) for having shared documents, brought logistical and scientific support, and facilitated access to outcrops in the Tiranimine, Tasdremt and Aoufour deposits. We thank Dr. L. Dewaide for her help and advice to collect samples on the field. We appreciate the help of Prof. J. Wouters and Dr. N. Tumanov of the PC2 platform (UNamur) for collecting XRD patterns. We also thank J.-P. Cullus and Prof. F. Boulvain for preparing thin sections, as well as P. Kubben and Prof. A. Bernard for making polished sections. This research also used the resources of the Electron Microscopy Service located at the University of Namur ("Plateforme Technologique Morphologie - Imagerie"). Y. Missenard and O. Parizot benefited from the French "Institut des Sciences de 1'Univers" (INSU) funding - Tellus-Syster program. We warmly thank P. Vasconcelos and T. De Putter for their careful and constructive review of this paper. Finally, we express gratitude to A. Gilg (editor) for handling this manuscript to its final version, as well as G. Beaudoin (editor-in-chief).

\section{Electronic supplementary material}

\section{ESM 1 ESM 2}

(KML $18 \mathrm{~kb})($ XLSX $77 \mathrm{~kb})$ 


\section{References}

AQ7

Algouti A, Algouti A, Taj-Eddine K (1999) Le Sénonien du Haut Atlas occidental, Maroc: sédimentologie, analyse séquentielle et paléogéographie. J Afr Earth Sci 29:643-658. https://doi.org/10.1016/S0899-5362(99)00121-9

Ambroggi R (1963) Etude géologique du versant méridional du haut atlas occidental et de la plaine du Souss. Notes Mém Serv Géologique Maroc 209-213

Amouri M, Bouaziz S, Ennifar S et al (1991) Le gîte manganésifère du Jebel Aziza (Chaine des Chotts): étude de la minéralisation dans son cadre morphostructural et paléogéographique. Notes Serv Géologique Tunis 58:133-150

Ayora C, Taberner C, Saaltink MW, Carrera J (1998) The genesis of dedolomites: a discusion based on reactive transport modeling. J Hydrol 209:346-365. https://doi.org/10.1016/S0022-1694(98)00095-X

Barnes HL (ed) (1997) Geochemistry of hydrothermal ore deposits, 3rd edn. New York, Wiley

Beauvais A, Ruffet G, Hénocque O, Colin F (2008) Chemical and physical erosion rhythms of the West African Cenozoic morphogenesis: the ${ }^{39} \mathrm{Ar}-{ }^{40} \mathrm{Ar}$ dating of supergene K-Mn oxides. J Geophys Res 113. https://doi.org/10.1029/2008JF000996

Bensalah MK, Youbi N, Mata J, Madeira J, Martins L, el Hachimi H, Bertrand H, Marzoli A, Bellieni G, Doblas M, Font E, Medina F, Mahmoudi A, Beraâouz EH, Miranda R, Verati C, de Min A, Ben Abbou M, Zayane R (2013) The Jurassic-Cretaceous basaltic magmatism of the Oued El-Abid syncline (High Atlas, Morocco): physical volcanology, geochemistry and geodynamic implications. J Afr Earth Sci 81:60-81. https://doi.org/10.1016/j.jafrearsci.2013.01.004 
Beukes NJ, Swindell EPW, Wabo H (2016) Manganese deposits of Africa. Episodes 39:285.

https://doi.org/10.18814/epiiugs/2016/v39i2/95779

Biagioni C, Capalbo C, Pasero M (2013) Nomenclature tunings in the hollandite supergroup. Eur J Mineral 25:85-90. https://doi.org/10.1127/0935-1221/2013/0025-2255

Bouabdellah M, Levresse G (2016) The Bou Madine Polymetallic Ore Deposit, Eastern Anti-Atlas, Morocco: evolution from massive $\mathrm{Fe}-\mathrm{As}-\mathrm{Sn}$ to epithermal $\mathrm{Au}-\mathrm{Ag}-\mathrm{Pb}-\mathrm{Zn} \pm \mathrm{Cu}$ mineralization in a Neoproterozoic Resurgent Caldera Environment. In: Bouabdellah M, Slack JF (eds) Mineral deposits of North Africa. Springer International Publishing, Cham, pp 133-142

Bouabdellah M, Sangster DF (2016) Geology, geochemistry, and current genetic models for major Mississippi valleytype $\mathrm{Pb}-\mathrm{Zn}$ deposits of Morocco. In: Bouabdellah M, Slack JF (eds) Mineral deposits of North Africa. Springer International Publishing, Cham, pp 463-495

Bouabdellah M, Maacha L, Levresse G, Saddiqi O (2016) The Bou Azzer Co-Ni-Fe-As( \pm Au \pm Ag) District of Central Anti-Atlas (Morocco): a long-lived Late Hercynian to Triassic magmatic-hydrothermal to low-sulphidation epithermal system. In: Bouabdellah M, Slack JF (eds) Mineral deposits of North Africa. Springer International Publishing, Cham, pp 229-247

Bouladon J (1948) Note sommaire sur Tiouine, Imini, Tasdremt. Centre National de Documentation, Rabat

Bouladon J, Jouravsky G (1952) Géologie des gites minéraux marocains: Manganèse. Alger, pp 44-80

Bouladon J, Jouravsky G (1953) Hollandite dans les gisements de manganèse du Maroc du Sud. Notes Mém Serv Géologique Maroc 7:253-255 
Bouladon J, Meune M (1951) le gisement de Tasdremt (Haut Sous): Un gîte sédimentaire de manganèse plombifère dans le mésocrétacé. Notes Mém Serv Géologique Maroc 4:221-250

Bouladon J, Jouravsky G, Colson C (1955) Les gisements de manganèse volcanogènes de Tiouine (Infracambrien du sud marocain): étude pétrographique et métallogénique. Notes Mém Serv Géologique Maroc 8:112

Buatier M, Choulet F, Petit S, Chassagnon R, Vennemann T (2016) Nature and origin of natural Zn clay minerals from the Bou Arhous $\mathrm{Zn}$ ore deposit: evidence from electron microscopy (SEM-TEM) and stable isotope compositions (H and O). Appl Clay Sci 132-133:377-390. https://doi.org/10.1016/j.clay.2016.07.004

Burns RG, Burns VM (1979) Manganese oxides. In: Marine minerals. Burns RG. Mineral Society of America, Washigton DC, pp 1-46

Charrière A, Haddoumi H, Mojon P-O, Ferrière J, Cuche D, Zili L (2009) Mise en évidence par charophytes et ostracodes de l'âge Paléocène des dépôts discordants sur les rides anticlinales de la région d'Imilchil (Haut Atlas, Maroc): conséquences paléogéographiques et structurales. Comptes Rendus Palevol 8:9-19.

https://doi.org/10.1016/j.crpv.2008.11.006

Cheilletz A, Ruffet G, Marignac C, Kolli O, Gasquet D, Féraud G, Bouillin JP (1999) ${ }^{40} \mathrm{Ar} /{ }^{39} \mathrm{Ar}$ dating of shear zones in the Variscan basement of Greater Kabylia (Algeria). Evidence of an Eo-Alpine event at $128 \mathrm{Ma}$ (Hauterivian-Barremian boundary): geodynamic consequences. Tectonophysics 306:97-116. https://doi.org/10.1016/S0040-1951(99)00047-5

Chester R, Jickells T (2012) Marine geochemistry. John Wiley \& Sons Ltd, Chichester

Choubert G (1957) Carte géologique du Maroc, 70, feuille de Marrakech

Choubert G, Faure-Muret A (1973) The Precambrian iron and manganese deposits of the Anti-Atlas. In: Genesis of

Precambrian iron and manganese deposits. Kiev, pp. 115-124 
Choulet F, Charles N, Barbanson L, Branquet Y, Sizaret S, Ennaciri A, Badra L, Chen Y (2014) Non-sulfide zinc deposits of the Moroccan High Atlas: multi-scale characterization and origin. Ore Geol Rev 56:115-140. https://doi.org/10.1016/j.oregeorev.2013.08.015

Colin F, Beauvais A, Ruffet G, Henocque O (2005) First ${ }^{40} \mathrm{Ar} /{ }^{39} \mathrm{Ar}$ geochronology of lateritic manganiferous pisolites: implications for the Palaeogene history of a West African landscape. Earth Planet Sci Lett 238:172-188.

https://doi.org/10.1016/j.epsl.2005.06.052

Corbella M, Ayora C, Cardellach E (2003) Dissolution of deep carbonate rocks by fluid mixing: a discussion based on reactive transport modeling. J Geochem Explor 78-79:211-214. https://doi.org/10.1016/S0375-6742(03)00032-3

Crerar DA, Cormick RK, Barnes HL (1972) Organic controls on the sedimentary geochemistry of manganese. Acta Mineral-Petrogr Szeged 20:217-226

De Putter T, Ruffet G (2020) Supergene manganese ore records 75 Myr-long Campanian to Pleistocene geodynamic evolution and weathering history of the Central African Great Lakes Region-tectonics drives, climate assists. Gondwana Res 83:96-117. https://doi.org/10.1016/j.gr.2020.01.021

De Putter T, Ruffet G, Yans J, Mees F (2015) The age of supergene manganese deposits in Katanga and its implications for the Neogene evolution of the African Great Lakes Region. Ore Geol Rev 71:350-362.

https://doi.org/10.1016/j.oregeorev.2015.06.015

De Putter T, Liégeois J-P, Dewaele S et al (2018) Paleoproterozoic manganese and base metals deposits at KisengeKamata (Katanga, D.R. Congo). Ore Geol Rev 96:181-200. https://doi.org/10.1016/j.oregeorev.2018.04.015

Decrée S, Deloule É, Ruffet G, Dewaele S, Mees F, Marignac C, Yans J, de Putter T (2010a) Geodynamic and climate controls in the formation of Mio-Pliocene world-class oxidized cobalt and manganese ores in the Katanga province, DR Congo. Mineral Deposita 45:621-629. https://doi.org/10.1007/s00126-010-0305-8 
Decrée S, Ruffet G, Putter TD, Baele JM, Recourt P, Jamoussi F, Yans J (2010b) Mn oxides as efficient traps for metal pollutants in a polyphase low-temperature Pliocene environment: a case study in the Tamra iron mine, Nefza mining district, Tunisia. J Afr Earth Sci 57:249-261. https://doi.org/10.1016/j.jafrearsci.2009.08.005

Dekoninck A, Bernard A, Barbarand J, Saint-Bezar B, Missenard Y, Lepretre R, Saddiqi O, Yans J (2016a) Detailed mineralogy and petrology of manganese oxyhydroxide deposits of the Imini district (Morocco). Mineral Deposita 51:13-23. https://doi.org/10.1007/s00126-015-0590-3

Dekoninck A, Leprêtre R, Saddiqi O, Barbarand J, Johan Y (2016b) The high-grade Imini manganese district-karsthosted deposits of mn oxides and oxyhydroxides. In: Bouabdellah M, Slack JF (eds) Mineral deposits of North Africa. Springer International Publishing, Cham, pp 575-594

Dekoninck A, Monié P, Blockmans S, Hatert F, Rochez G, Yans J (2019) Genesis and 40Ar/39Ar dating of K-Mn oxides from the Stavelot Massif (Ardenne, Belgium): insights into Oligocene to Pliocene weathering periods in Western Europe. Ore Geol Rev 115:103-191. https://doi.org/10.1016/j.oregeorev.2019.103191

Dewaide L, Baele J-M, Collon-Drouaillet P et al (2014) Karstification in dolomitized Waulsortian mudmounds (Belgium). Geol Belg 17:43-51

Dresch J (1941) Recherches sur l'évolution du relief dans le Massif central du Grand Atlas, le Haouz et le Sous. Unpublished Ph.D. thesis

Dreybrodt W (1988) Processes in karst systems: physics, chemistry, and geology. Springer-Verlag, Berlin Heidelberg

Dubois M, Lopez M, Orberger B, Gay A, Moussavou M, Pambo F, Rodrigues S (2017) The 2.1 Ga-old injectite network of the Franceville Basin, Gabon: architecture, origin and implications on manganese mineralization. Precambrian Res 302:255-278. https://doi.org/10.1016/j.precamres.2017.09.022 
Fleck RJ, Sutter JF, Elliot DH (1977) Interpretation of discordant 40Ar/39Ar age-spectra of mesozoic tholeiites from Antarctica. Geochim Cosmochim Acta 41:15-32. https://doi.org/10.1016/0016-7037(77)90184-3

Force ER, Back W, Spiker EC, Knauth LP (1986) A ground-water mixing model for the origin of the Imini manganese deposit (Cretaceous) of Morocco. Econ Geol 81:65-79. https://doi.org/10.2113/gsecongeo.81.1.65

Frizon de Lamotte D, Saint Bezar B, Bracène R, Mercier E (2000) The two main steps of the Atlas building and geodynamics of the western Mediterranean. Tectonics 19:740-761. https://doi.org/10.1029/2000TC900003

Frizon de Lamotte D, Zizi M, Missenard Y, Hafid M, Azzouzi ME, Maury RC, Charrière A, Taki Z, Benammi M, Michard A (2008) The Atlas system. In: Michard A, Saddiqi O, Chalouan A, de Lamotte DF (eds) Continental evolution: the geology of Morocco. Springer, Berlin Heidelberg, pp 133-202

Frizon de Lamotte D, Leturmy P, Missenard Y et al (2009) Mesozoic and Cenozoic vertical movements in the Atlas system (Algeria, Morocco, Tunisia): an overview. Tectonophysics 475:9-28. https://doi.org/10.1016/j.tecto.2008.10.024

Froitzheim N (1984) Late Cretaceous vertical tectonics in the High Atlas SW of Marrakech/Morocco-reconstruction of tectonic movements in an early stage of the High Atlas orogenesis. Neues Jahrb Für Geol Paläontol-Monatshefte 1984:463-471

Froitzheim N, Stets J, Wurster P (1988) Aspects of Western High Atlas tectonics. In: Jacobshagen VH (ed) The Atlas system of Morocco. Springer-Verlag, Berlin/Heidelberg, pp 219-244

Fullea J, Fernàndez M, Zeyen H, Vergés J (2007) A rapid method to map the crustal and lithospheric thickness using elevation, geoid anomaly and thermal analysis. Application to the Gibraltar Arc System, Atlas Mountains and adjacent zones.

Tectonophysics 430:97-117. https://doi.org/10.1016/j.tecto.2006.11.003 
Fullea J, Fernàndez M, Afonso JC, Vergés J, Zeyen H (2010) The structure and evolution of the lithosphereasthenosphere boundary beneath the Atlantic-Mediterranean Transition Region. Lithos 120:74-95. https://doi.org/10.1016/j.lithos.2010.03.003

Garnit H, Kraemer D, Bouhlel S, Davoli M, Barca D (2020) Manganese ores in Tunisia: genetic constraints from trace element geochemistry and mineralogy. Ore Geol Rev 120:103451. https://doi.org/10.1016/j.oregeorev.2020.103451

Garrels RM, Christ CL (1965) Solutions, minerals, and equilibria. Harper \& Row Publ, New York

Gasquet D, Levresse G, Cheilletz A, Azizi-Samir MR, Mouttaqi A (2005) Contribution to a geodynamic reconstruction of the Anti-Atlas (Morocco) during Pan-African times with the emphasis on inversion tectonics and metallogenic activity at the Precambrian-Cambrian transition. Precambrian Res 140:157-182.

https://doi.org/10.1016/j.precamres.2005.06.009

Gaudefroy C, Bouladon J, Permingeat F (1965) Une chlorite magnésienne (corundophyllite) du gîte de manganèse de Tachgagalt (Anti-Atlas) et sa signification génétique. Notes Mém Serv Géologique Maroc 24:95-98

Ghanmi M, Potfaj M (1991) Données stratigraphiques sur la chaine de Tébega de Kébeli, Jebel Aziza (Tunisie méridionale): conséquence paléogéographiques et tectoniques. Notes Serv Géologique Tunis 58:21-28

Gouiza M, Charton R, Bertotti G, Andriessen P, Storms JEA (2017) Post-Variscan evolution of the Anti-Atlas belt of Morocco constrained from low-temperature geochronology. Int J Earth Sci 106:593-616. https://doi.org/10.1007/s00531016-1325-0

Grant JA (1986) The isocon diagram; a simple solution to Gresens' equation for metasomatic alteration. Econ Geol 81:1976-1982. https://doi.org/10.2113/gsecongeo.81.8.1976 
Gresens RL (1967) Composition-volume relationships of metasomatism. Chem Geol 2:47-65.

https://doi.org/10.1016/0009-2541(67)90004-6

Gresse PG, Chevallier LP, De Beer CH et al (2000) Mémoire explicatif de la carte géologique du Maroc au 1/50 000 feuille Tachoukacht. Notes Mém Serv Géologique Maroc 393 bis:108

Gutzmer J, Beukes NJ (1996) Mineral paragenesis of the Kalahari managanese field, South Africa. Ore Geol Rev 11:405-428. https://doi.org/10.1016/S0169-1368(96)00011-X

Gutzmer J, Beukes NJ, Rhalmi M, Mukhopadhyay J (2006) Cretaceous karstic cave-fill manganese-lead-barium deposits of Imini, Morocco. Econ Geol 101:385-405. https://doi.org/10.2113/gsecongeo.101.2.385

Gutzmer J, Du Plooy AP, Beukes NJ (2012) Timing of supergene enrichment of low-grade sedimentary manganese ores in the Kalahari Manganese Field, South Africa. Ore Geol Rev 47:136-153.

https://doi.org/10.1016/j.oregeorev.2012.04.003

Hanes JA, York D, Hall CM (1985) $\mathrm{An}{ }^{40} \mathrm{Ar} /{ }^{39} \mathrm{Ar}$ geochronological and electron microprobe investigation of an Archaean pyroxenite and its bearing on ancient atmospheric compositions. Can J Earth Sci 22:947-958.

https://doi.org/10.1139/e85-100

Hautmann S, Lippolt HJ (2000) ${ }^{40} \mathrm{Ar} /{ }^{39} \mathrm{Ar}$ dating of central European K Mn oxides a chronological framework of supergene alteration processes during the Neogene. Chem Geol 170:37 80. https://doi.org/10.1016/S0009-2541(99)002417

Hem JD (1963) Chemical equilibria affecting the behavior of manganese in natural water. Int Assoc Sci Hydrol Bull 8:30-37. https://doi.org/10.1080/02626666309493334 
Hénocque O, Ruffet G, Colin F, Féraud G (1998) ${ }^{40} \mathrm{Ar} /{ }^{39} \mathrm{Ar}$ dating of West African lateritic cryptomelanes. Geochim Cosmochim Acta 62:2739-2756. https://doi.org/10.1016/S0016-7037(98)00185-9

Herbig H-G (1988) Synsedimentary tectonics in the Northern Middle Atlas (Morocco) during the late Cretaceous and Tertiary. In: Jacobshagen VH (ed) The Atlas system of Morocco: studies on its geodynamic evolution. Springer, Berlin Heidelberg, pp $321-337$

Herbig H-G, Trappe J (1994) Stratigraphy of the Subatlas Group (Maastrichtian-Middle Eocene, Morocco). Newsl Stratigr 30:125-165. https://doi.org/10.1127/nos/30/1994/125

Hoffman EL (1992) Instrumental neutron activation in geoanalysis. J Geochem Explor 44:297-319. https://doi.org/10.1016/0375-6742(92)90053-B

Hollard H (1985) Carte géologique du Maroc:260

Jiménez-Munt I, Fernàndez M, Vergés J, Garcia-Castellanos D., Fullea J., Pérez-Gussinyé M., Afonso J.C. (2011) Decoupled crust-mantle accommodation of Africa-Eurasia convergence in the NW Moroccan margin. J Geophys Res 116. https://doi.org/10.1029/2010JB008105

Jouravsky G (1958) Quelques observations nouvelles sur des gîtes de manganèse du Maroc. Mines Géologie Energ 48

Jouravsky G (1963) Filons de manganèse dans les formations volcaniques du Précambrien III de 1'Anti-Atlas. Etude métallogénique. Notes Mém Serv Géologique Maroc 22:81-92

Jouravsky G, Pouit G (1963) Filons et couches de manganèse dans la région d'El-Borj (Anti-Atlas). Notes Mém Serv Géologique Maroc 22:93-98

Kuleshov V (2016) Isotope geochemistry: the origin and formation of manganese rocks and ores. Elsevier, Amsterdam Boston Heidelberg London New York Oxford Paris San Diego San Francisco Singapore Sydney Tokyo 
Lafforgue L (2016) Place de la minéralisation de manganèse de Bouarfa dans l'évolution méso-cénozoique de l'oriental marocain. PhD, Université Paris Sud

Lafforgue L, Barbarand J, Missenard Y, et al (2015) Origin of the Bouarfa manganese ore deposit (Eastern High Atlas, Morocco): insights from petrography and geochemistry of the mineralization. Nancy

Lalaoui MD, Beauchamp J, Sagon J-P (1991) Le gisement de manganèse de l'Imini (Maroc): un dépôt sur la ligne de rivage. Chron Rech Minière 23-36

Leclerc J, Weber F (1980) Geology and genesis of the Moanda manganese deposits, Republic of Gabon. In: In: Geology and geochemistry of manganese. Vol. II. Manganese deposits on continents. Publishing House of Hungarian Academy of Sciences, Budapest, pp 89-109

Leprêtre R, Missenard Y, Barbarand J, Gautheron C, Saddiqi O, Pinna-Jamme R (2015a) Postrift history of the eastern central Atlantic passive margin: insights from the Saharan region of South Morocco: Postrift Evolution Moroccan Margin. J Geophys Res Solid Earth 120:4645-4666. https://doi.org/10.1002/2014JB011549

Leprêtre R, Missenard Y, Saint-Bezar B, Barbarand J, Delpech G, Yans J, Dekoninck A, Saddiqi O (2015b) The three main steps of the Marrakech High Atlas building in Morocco: structural evidences from the southern foreland, Imini area. J Afr Earth Sci 109:177-194. https://doi.org/10.1016/j.jafrearsci.2015.05.013

Leprêtre R, Barbarand J, Missenard Y, Gautheron C, Pinna-Jamme R, Saddiqi O (2017) Mesozoic evolution of NW Africa: implications for the Central Atlantic Ocean dynamics. J Geol Soc 174:817-835. https://doi.org/10.1144/jgs2016100

Leprêtre R, Missenard Y, Barbarand J, Gautheron C, Jouvie I, Saddiqi O (2018) Polyphased inversions of an intracontinental rift: case study of the Marrakech High Atlas, Morocco. Tectonics 37:818-841.

https://doi.org/10.1002/2017TC004693 
Lesavre A (1975) Le gisement de manganèse d’Imini (Maroc). PhD, Pierre-et-Marie-Curie

Li Y-H (2000) A compendium of geochemistry: from solar nebula to the human brain. Princeton University Press, Princeton

Li J-W, Vasconcelos P, Zhang W, Deng XD, Duzgoren-Aydin N, Yan DR, Zhang JQ, Hu MA (2007) Timing and duration of supergene mineralization at the Xinrong manganese deposit, western Guangdong Province, South China: cryptomelane ${ }^{40} \mathrm{Ar} /{ }^{39} \mathrm{Ar}$ dating. Mineral Deposita 42:361-383. https://doi.org/10.1007/s00126-006-0118-y

Lippolt HJ, Hautmann S (1995) ${ }^{40} \mathrm{Ar} /{ }^{39} \mathrm{Ar}$ ages of Precambrian manganese ore minerals from Sweden, India and Morocco. Mineral Deposita 30:246-256. https://doi.org/10.1007/BF00196360

López-Moro FJ (2012) EASYGRESGRANT_A Microsoft Excel spreadsheet to quantify volume changes and to perform mass-balance modeling in metasomatic systems. Comput Geosci 39:191-196.

https://doi.org/10.1016/j.cageo.2011.07.014

Maynard JB (2014) Manganiferous sediments, rocks, and ores. In: Treatise on Geochemistry. Elsevier, pp. 327-349

Michard A, Saddiqi O, Missenard Y, et al (2017) Les grandes régions géologiques du Maroc; diversité et soulèvement d'ensemble. Géologues Rev Off Société Géologique Fr 4-12

Missenard Y, Zeyen H, Frizon de Lamotte D et al (2006) Crustal versus asthenospheric origin of relief of the Atlas Mountains of Morocco. J Geophys Res Solid Earth 111:n/a. https://doi.org/10.1029/2005JB003708

Missenard Y, Taki Z, Frizon de Lamotte D, Benammi M, Hafid M, Leturmy P, Sébrier M (2007) Tectonic styles in the Marrakesh High Atlas (Morocco): the role of heritage and mechanical stratigraphy. J Afr Earth Sci 48:247-266.

https://doi.org/10.1016/j.jafrearsci.2007.03.007 
Missenard Y, Saddiqi O, Barbarand J, Leturmy P, Ruiz G, el Haimer FZ, Frizon de Lamotte D (2008) Cenozoic denudation in the Marrakech High Atlas, Morocco: insight from apatite fission-track thermochronology. Terra Nova 20:221-228. https://doi.org/10.1111/j.1365-3121.2008.00810.x

Mouttaqi A, Rjimati EC, Maacha L, et al (2011) Les principales mines du Maroc, Editions du Service Géologique du Maroc. Ministère de l'Energie, des Mines, de l'Eau et de l'Environnement, Rabat

Neltner L (1938) Etudes géologique dans le Sud Marocain (Haut-Atlas et Anti-Atlas). Notes Mém Serv Géologique Maroc

Nicholson K (1992) Contrasting mineralogical-geochemical signatures of manganese oxides; guides to metallogenesis. Econ Geol 87:1253-1264. https://doi.org/10.2113/gsecongeo.87.5.1253

Office National des Mines et des Hydrocarbures (2016) District de manganèse de Tasdremt-Aoufour (province de Taroudant, Maroc). Rabat

Parizot O (2017) Contexte structural du gisement manganésifère de Tasdremt, Bassin du Souss, Maroc. Mémoire, Université Paris Sud

Perseil EA, Grandin G (1978) Evolution minéralogique du manganèse dans trois gisements d'Afrique de l'Ouest: Mokta, Tambao, Nsuta. Mineral Deposita 13:295-311. https://doi.org/10.1007/BF00206565

Perseil E-A, Grandin G (1985) Altération supergène des protores à grenats manganésifères dans quelques gisements d'Afrique de I'Ouest. Mineral Deposita 20:211-219

Post JE (1999) Manganese oxide minerals: crystal structures and economic and environmental significance. Proc Natl Acad Sci 96:3447-3454. https://doi.org/10.1073/pnas.96.7.3447 
Potdevin J-L, Marquer D (1987) Quantitative methods for the estimation of mass transfers by fluids in deformed metamorphic rocks. Geodin Acta 1:193-206. https://doi.org/10.1080/09853111.1987.11105138

Pouit G (1964) Les gîtes de manganèse marocains encaissés dans les Formations carbonatées: éléments pour une synthèse. Chron Mines Rech Minière 371-380

Pouit G (1966) Le manganèse dans le Permo-Trias au Maroc: étude métallogénique et comparaison avec les minéralisations dans le Précambrien III. Notes Mém Serv Géologique Maroc 27:117-122

Pouit G (1976) La concentration de manganèse de l'Imini (Maroc) peut-elle être d'origine karstique ? Comptes Rendus Somm Société Géologique Fr 5:227-229

Pouit G (1980) Manganèse. Notes Mém Serv Géologique Maroc Rabat 13:61-67

Pouit G, Jouravsky G (1960) Présence de filons de manganèse d’âge post-triasique ou post-Cénomanien dans la région de 1’Imini. Notes Mém Serv Géologique Maroc 19:61-67

Pouit G, Jouravsky G (1961) Les indices de manganèse du Jbel Sour (Haut Atlas de Marrakech): Relation entre minéralisation et structure paléinsulaire. Mines Géologie Energ 36-37

Pouit G, Jouravsky G (1962) Le gîte de manganèse d'Aït-Iggelt (Anti-Atlas): un exemple de minéralisation pénécontemporaine de la série encaissante. Mines Géologie Energ 41-47

Rhalmi M, Pascal A, Lang J (1997) Contrôle sédimentaire et diagénétique de la minéralisation manganésifère au cours du Crétacé Supérieur dans la région d'Imini (Haut-Atlas central, Maroc). Comptes Rendus L’Académie Sci Sér 2 Sci Terre Planètes 323:213-220

Rhalmi M, Pascal A, Chellai E (2000) Lithobiostratigraphie, diagenèse et paléogéographie au Cénomanien supérieurTuronien inférieur des bassins sud-atlasiques marocains. Géologie Alp 76:135-149 
Roddick JC, Cliff RA, Rex DC (1980) The evolution of excess argon in alpine biotites - a 40Ar-39Ar analysis. Earth Planet Sci Lett 48:185-208. https://doi.org/10.1016/0012-821X(80)90181-8

Ruffet G, Féraud G, Amouric M (1991) Comparison of 40Ar-39Ar conventional and laser dating of biotites from the North Trégor Batholith. Geochim Cosmochim Acta 55:1675-1688. https://doi.org/10.1016/0016-7037(91)90138-U

Ruffet G, Féraud G, Balèvre M, Kiénast J-R (1995) Plateau ages and excess argon in phengites: an 40Ar 39Ar laser probe study of Alpine micas (Sesia Zone, Western Alps, Northern Italy). Chem Geol 121:327-343. https://doi.org/10.1016/00092541(94)00132-R

Ruffet G, Innocent C, Michard A, Féraud G, Beauvais A, Nahon D, Hamelin B (1996) A geochronological and study of K-Mn oxides from the weathering sequence of Azul, Brazil. Geochim Cosmochim Acta 60:2219-2232. https://doi.org/10.1016/00167037(96)00080-4

Ruffet G, Gruau G, Ballèvre M, Féraud G, Philippot P (1997) Rb/Sr and ${ }^{40} \mathrm{Ar} /{ }^{39}$ Ar laser probe dating of high-pressure phengites from the Sesia zone (Western Alps): underscoring of excess argon and new age constraints on the highpressure metamorphism. Chem Geol 141:1-18. https://doi.org/10.1016/S0009-2541(97)00052-1

Ruiz GMH, Sebti S, Negro F, Saddiqi O, Frizon de Lamotte D, Stockli D, Foeken J, Stuart F, Barbarand J, Schaer JP (2011) From central Atlantic continental rift to Neogene uplift-western Anti-Atlas (Morocco): from central Atlantic continental rift to Neogene uplift. Terra Nova 23:35-41. https://doi.org/10.1111/j.1365-3121.2010.00980.x

Sebbag I (1969) Inventaire général des gîtes et indices de cuivre, manganèse, plomb, fer, or et argent du Jbel Sarhro oriental. Mines Géologie Energ 35-48

Seber D, Barazangi M, Tadili BA, Ramdani M, Ibenbrahim A, Ben Sari D (1996) Three-dimensional upper mantle structure beneath the intraplate Atlas and interplate Rif mountains of Morocco. J Geophys Res Solid Earth 101:3125-3138.

https://doi.org/10.1029/95JB03112 
Sebti S (2011) Mouvements Verticaux de l'Anti-Atlas Occidental marocain (Kerdous \& Ifni): Thermochronologie par traces de fission. Unpublished Ph.D. thesis, Hassan II-Aïn Chock

Stone AT (1987) Reductive dissolution of manganese (III/IV) oxides by substituted phenols. Environ Sci Technol 21:979-988. https://doi.org/10.1021/es50001a011

Stone AT, Morgan JJ (1984a) Reduction and dissolution of manganese (III) and manganese (IV) oxides by organics: 2. Survey of the reactivity of organics. Environ Sci Technol 18:617-624. https://doi.org/10.1021/es00126a010

Stone AT, Morgan JJ (1984b) Reduction and dissolution of manganese (III) and manganese (IV) oxides by organics. 1. Reaction with hydroquinone. Environ Sci Technol 18:450-456. https://doi.org/10.1021/es00124a011

Teixell A, Ayarza P,Zeyen H, Fernandez M, Arboleya ML (2005) Effects of mantle upwelling in a compressional setting: the Atlas Mountains of Morocco. Terra Nova 17:456-461. https://doi.org/10.1111/j.1365-3121.2005.00633.X

Thein J (1990) Paleogeography and geochemistry of the "Cenomano-Turonian" formations in the manganese district of Imini (Morocco) and their relation to ore deposition. Ore Geol Rev 5:257-291. https://doi.org/10.1016/0169- 1368(90)90034-K

Thomas RJ, Chevallier LP, De Beer CH et al (2000) Mémoire explicatif de la carte géologique du Maroc au 1/50 000 feuille Tazentoute. Notes Mém Serv Géologique Maroc 393 bis:108

Turekian KK, Holland HD (2014) Treatise on geochemistry. Elsevier Science

Turner G (1971) ${ }^{40} \mathrm{Ar} /{ }^{39} \mathrm{Ar}$ ages from the lunar maria. Earth Planet Sci Lett 11:169-191. https://doi.org/10.1016/0012$821 \mathrm{X}(71) 90161-0$

Turner S, Buseck PR (1979) Manganese oxide tunnel structures and their intergrowths. Science 203:456-458.

https://doi.org/10.1126/science.203.4379.456 
Vafeas NA, Blignaut LC, Viljoen KS, Meffre S (2018a) New evidence for the early onset of supergene alteration along the Kalahari unconformity. South Afr J Geol 121:157-170. https://doi.org/10.25131/sajg.121.0012

Vafeas NA, Viljoen KS, Blignaut LC (2018b) Characterization of fibrous cryptomelane from the todorokite- cryptomelane mineral assemblage at the Sebilo Mine, Northern Cape Province, South Africa. Can Mineral 56:65-76. https://doi.org/10.3749/canmin.1700043

Varentsov IM (1996) Manganese ores of supergene zone: geochemistry of formation. Springer Netherlands, Dordrecht

Vasconcelos PM (1999) K-Ar and ${ }^{40} \mathrm{Ar} /{ }^{39} \mathrm{Ar}$ geochronology of weathering processes. Annu Rev Earth Planet Sci 27:183-229. https://doi.org/10.1146/annurev.earth.27.1.183

Vasconcelos PM, Becker TA, Renne PR, Brimhall GH (1992) Age and duration of weathering by ${ }^{40} \mathrm{~K} /{ }^{40} \mathrm{Ar}$ and ${ }^{40} \mathrm{Ar} /{ }^{39} \mathrm{Ar}$ analysis of potassium-manganese oxides. Science 258:451-455. https://doi.org/10.1126/science.258.5081.451

Vasconcelos PM, Renne PR, Brimhall GH, Becker TA (1994) Direct dating of weathering phenomena by ${ }^{40} \mathrm{Ar} /{ }^{39} \mathrm{Ar}$ and $\mathrm{K}-\mathrm{Ar}$ analysis of supergene K-Mn oxides. Geochim Cosmochim Acta 58:1635-1665. https://doi.org/10.1016/0016- 7037(94)90565-7

Vasconcelos PM, Renne PR, Becker TA, Wenk H-R (1995) Mechanisms and kinetics of atmospheric, radiogenic, and nucleogenic argon release from cryptomelane during analysis. Geochim Cosmochim Acta 59:2057-2070.

https://doi.org/10.1016/0016-7037(95)00126-3

Verati C, Rapaille C, Féraud G, Marzoli A, Bertrand H, Youbi N (2007) ${ }^{40} \mathrm{Ar} /{ }^{39} \mathrm{Ar}$ ages and duration of the Central Atlantic Magmatic Province volcanism in Morocco and Portugal and its relation to the Triassic-Jurassic boundary. Palaeogeogr Palaeoclimatol Palaeoecol 244:308-325. https://doi.org/10.1016/j.palaeo.2006.06.033 
Verhaert M, Bernard A, Dekoninck A, Lafforgue L, Saddiqi O, Yans J (2017) Mineralogical and geochemical characterization of supergene $\mathrm{Cu}-\mathrm{Pb}-\mathrm{Zn}-\mathrm{V}$ ores in the Oriental High Atlas, Morocco. Mineral Deposita 52:1049-1068.

https://doi.org/10.1007/s00126-017-0753-5

Verhaert M, Bernard A, Saddiqi O, Dekoninck A, Essalhi M, Yans J (2018) Mineralogy and genesis of the polymetallic and polyphased low grade Fe-Mn-Cu ore of Jbel Rhals deposit (Eastern High Atlas, Morocco). Minerals 8:39.

https://doi.org/10.3390/min8020039

Weber F (1973) Genesis and supergene evolution of the Precambrian sedimentary manganese at Moanda (Gabon). In: Proceedings of the Kiev Symposium. UNESCO, Paris, pp 284-299

Westerveld J (1951) Les gîtes de manganèse du domaine atlasique au Maroc français et leur classification géologique. Geol En Mijnb 2:25-52

York D (1968) Least squares fitting of a straight line with correlated errors. Earth Planet Sci Lett 5:320-324. https://doi.org/10.1016/S0012-821X(68)80059-7

York D, Evensen NM, Martinez ML, De Basabe Delgado J (2004) Unified equations for the slope, intercept, and standard errors of the best straight line. Am J Phys 72:367-375. https://doi.org/10.1119/1.1632486

Youbi N, Kouyaté D, Söderlund U, Ernst RE, Soulaimani A, Hafid A, Ikenne M, el Bahat A, Bertrand H, Rkha Chaham K, Ben Abbou M, Mortaji A, el Ghorfi M, Zouhair M, el Janati M' (2013) The 1750 Ma magmatic event of the West African Craton (Anti-Atlas, Morocco). Precambrian Res 236:106-123. https://doi.org/10.1016/j.precamres.2013.07.003

Zeyen H, Ayarza P, Fernàndez M, Rimi A (2005) Lithospheric structure under the western African-European plate boundary: a transect across the Atlas Mountains and the Gulf of Cadiz: Atlas-Gulf of Cadiz lithosphere. Tectonics 24:116 n/a-n/a. https://doi.org/10.1029/2004TC001639 
Zouhri S, Kchikach A, Saddiqi O, Haïmer FZE, Baidder L, Michard A (2008) The Cretaceous-Tertiary plateaus. In: Michard A, Saddiqi O, Chalouan A, de Lamotte DF (eds) Continental evolution: the geology of Morocco. Springer, Berlin Heidelberg, pp 331-358

Paul R. Renne, Carl C. Swisher, Alan L. Deino, Daniel B. Karner, Thomas L. Owens, Donald J. DePaolo, (1998) Intercalibration of standards, absolute ages and uncertainties in 40Ar/39Ar dating. Chemical Geology 145 (1-2):117-152

Paul R. Renne, Roland Mundil, Greg Balco, Kyoungwon Min, Kenneth R. Ludwig, (2010) Joint determination of 40K decay constants and 40Ar*/40K for the Fish Canyon sanidine standard, and improved accuracy for 40Ar/39Ar geochronology. Geochimica et Cosmochimica Acta 74 (18):5349-5367

Paul R. Renne, Greg Balco, Kenneth R. Ludwig, Roland Mundil, Kyoungwon Min, (2011) Response to the comment by W.H. Schwarz et al. on "Joint determination of $40 \mathrm{~K}$ decay constants and 40Ar*/40K for the Fish Canyon sanidine standard, and improved accuracy for 40Ar/39Ar geochronology" by P.R. Renne et al. (2010). Geochimica et Cosmochimica Acta 75 (17):5097-5100 